\title{
Hubert Szczęśniak
}

\section{Musical Sources Survived in the Collection of the Auschwitz-Birkenau State Museum'}

\section{Abstract}

The article presents the conclusions of the research conducted by the author in the collection of the Auschwitz-Birkenau State Museum, former German Nazi concentration and extermination camp. The sources are fully featured and described for the first time. The article focuses on showing a complicated post-war history of the items connected with music (musical instruments, printings, manuscripts, handwritten copies of instrumental books), which are auxiliary sources to reconstruct the repertoire of chapels in KL Auschwitz-Birkenau. The main aim of the article is also to discuss the preserved repertoire. In the last chapter, the author presents a short characteristics of original works composed by musicians and composers in slavery with a short analysis of all of them. Presented musical printings are a reflection of tastes of the German public in the 1930 s as well as an example of ridiculous anthropological establishments of Nazi music scientists and the lack of ability to implement it on listeners practice. In addition, the work con-

1 The article is based on the last chapter of the BA thesis titled: Nieznane oblicza muzyki. Muzyka w KL Auschwitz na przykładzie działalności kapel więźniarskich, written under guidance of Dr. Wojciech Marchwica and defended by the author in July 2016 at the Institute of Musicology of the Jagiellonian University. Previous two chapters concern issues of the state of research on music in Auschwitz-Birkenau and the role of chapels in the reality of a camp, including its functions. 
tains annexes: musical instruments, original works composed during camp existence, and musical printings-a list of music materials which survived in the collection of the Auschwitz-Birkenau State Museum.

\section{Keywords}

KL Auschwitz-Birkenau, musical sources, Holocaust Music, Music and Politics, Auschwitz-Birkenau State Museum

Nie jest to bowiem książka o muzyce. Jest to ksiązka o muzyce w hitlerowskim obozie koncentracyjnym. Można by również rzec: o muzyce w krzywym zwierciadle [...] (Szymon Laks) ${ }^{2}$

Compositions and musical instruments used by the chapels of inmates of KL Auschwitz-Birkenau, ${ }^{3}$ kept in the Collections Departament of the Auschwitz-Birkenau State Museum, ${ }^{4}$ have not been studied as a whole

2 In English: "Because it is not a book about music. / It is a book about music in Nazi / concentration camp. It could be also said: / about music in a distorting mirror [...]". See: Sz. Laks, Gry oświęcimskie, Oświęcim 1998, p. 11. These words open the camp memories of the composer and conductor of a male chapel in Birkenau and should be recalled by the reader when reading this article.

3 The concentration camp, during the time of its existence, was systematically expanded, and as a result it contained three main parts: main camp, since 1943 called Auschwitz I, Birkenau (Auschwitz II) and Monowitz (Auschwitz III) together with tens of sub-camps. See e.g.: D. Czech, Kalendarz wydarzeń w KL Auschwitz, Oświęcim 1992; Auschwitz. Nazistowski obóz śmierci, ed. F. Piper, T. Świebocka, Oświęcim 2004; Auschwitz 1940-1945. Węzłowe zagadnienia z dziejów obozu, ed. W. Długoborski, F. Piper, Oświęcim 1995; P. Setkiewicz, Z dziejów obozów IG Farben Werk Auschwitz 1941-1945, Oświęcim 2006; idem., Krematoria i komory gazowe Auschwitz, Oświęcim 2010.

Beside the male chapel active in the main camp (Auschwitz I), we can distinguish chapels playing in subcamps: male in Birkenau (Auschwitz II), female in Birkenau, male in Monowitz (Auschwitz III) and many smaller ensembles performing music. See: J. Lachendro, Orkiestry w KL Auschwitz, "Zeszyty Oświęcimskie” 27 (2012).

4 In the further part of a paper, the author uses abbreviation PMA-B when referring to the Auschwitz-Birkenau State Museum. 
yet. However, Jacek Lachendro ${ }^{5}$ made an attempt to reconstruct the repertoire performed by camp chapels, but his research was based mainly on memories written down by inmates. Due to this, it is probable that repertoires from different Nazi concentration camps are mixed as numerous prisoners-musicians were relocated to other camps after the evacuation of Auschwitz-Birkenau, in which they performed music as well. Taking the imperfection of human memory into consideration, especially when it comes to extremely traumatic situations, we should treat their reports carefully. Moreover, in those reports the repertoire is less significant, and what is more important is the role of chapel in the reality of a camp and influence of music on prisoners as well as on torturers.

Starting a detailed analysis of a musical activity in the Nazi concentration camps, we should begin with everything what is preserved after chapels, confronting such data as precisely as possible with information given by people who were rescued during the Holocaust. To complete this task, at least fragmentarily, is the aim of this article. The author confined himself to present the sources not described before; in terms of history of chapels, he refers to reliable and up-to-date literature. ${ }^{6}$

\section{The Amount of Preserved Material and Its Origin}

In the Department of Collection of the Auschwitz-Birkenau State Museum, there are 229 positions in the catalogue that are connected with the activity of the chapels from Auschwitz. ${ }^{7}$ The first group of them consists of instruments and musical accessories, from which now we have only: clarinet in $\mathrm{B}$, , bass tuba, accordion and violin, as well as one metal music stand.

5 J. Lachendro, op. cit., p. 9.

6 History of chapels of KL Auschwitz-Birkenau was precisely studied by Jacek Lachendro. See: ibid., passim.

$7 \quad$ Ibid., p. 9, ref. 6. Jacek Lachendro says that musical sources preserved in the Department of Collections of the Auschwitz-Birkenau State Museum are an archivist part of the collection, namely cat. Nos. from PMO-II-4-180 to PMO-II-4-630/24. However, not all the catalogue numbers from this part are connected with the activity of the chapels. Between them, other devices, not connected with them, can be found. What is more, in the case of musical sources, and especially scores (both prints and hand-written parts), one catalogue number consists of several different works, which is caused by the order in which next works were obtained and included in the collection after war. 
The significant sources for studies on the musical activity in the German concentration camps are, rarely preserved in the case of the AuschwitzBirkenau collection, works composed by inmates-musicians during the war. The rest of objects kept there are musical prints, published in Germany and Austria in the first three decades of the 2oth century, as well as hand-written copies of parts, prepared based on those prints by inmates-copyists. Among discussed sources, there are also several musical works (manuscripts and prints) written after the war and sent by the authors-former inmates-to the museum of a camp.

After sorting the scores, it was possible to complete circa 200 preserved works, both prints and manuscripts. Their provenance is confirmed by the three-line seal of the chapel, by which new scores were stamped (Illustr. 1).

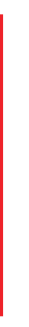

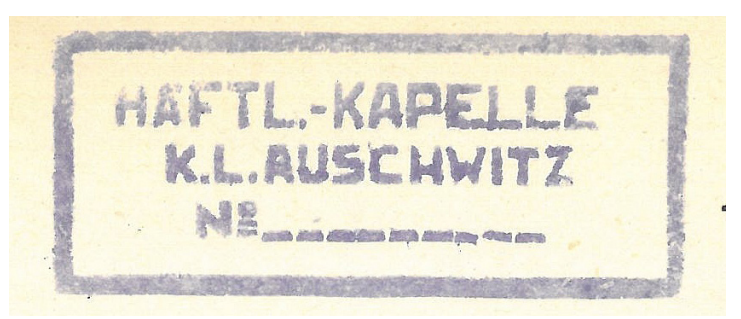

Illustr. 1: Three-line seal of the chapel. ${ }^{8}$

A section "No_____," put in the last line, was not filled in. The catalogue number was, however, written on the cardboard folder, in which scores were kept. The author of this article has not found any report containing information about the origin of this seal, what makes it more difficult to decide whether the idea was initiated by the authorities of the camp or by the musicians. Considering the fact that stocktaking of the scores used in the camp was undertaken by putting the number on the folders, it seems convincing that the seal could be a German initiative, created probably by the Nazi administrative machine.

On each folder, there is a title or two titles of musical works, what proves the fact that folders were used several times. ${ }^{9}$ Two types of them

\footnotetext{
8 Source: the Collections Department of Auschwitz-Birkenau State Museum.

9 In all likelihood, in one folder there were two or more works. It is proved by titles written on the averse and reverse pages of certain folders.
} 
can be distinguished, what is additionally helpful when it comes to the identification of the origin of the sources not having the seal described above. The first type are navy blue folders (ca. 78 preserved) with the canvas ridge and a decorative square sticker in the middle (Illustr. 2).

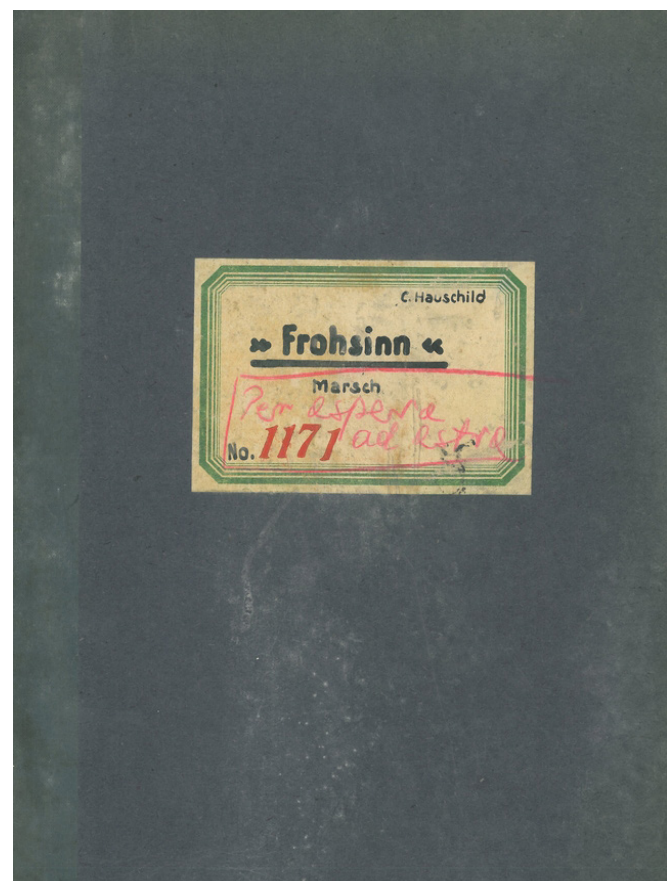

Illustr. 2: A navy blue folder for scores. On the title sticker, the hand-written Latin phrase Per aspera ad astra ("Through hardships to the stars"), which is at the same time a title of one of the preserved works. ${ }^{10}$

On the sticker, in a frame, there is a title, carefully and calligraphically written in black ink and underlined; frequently, a genre of a work and a subtitle appear as well. The name of the author is written in the same way in the upper-right corner. In the bottom-left corner, there is a number written in red ink, repeated on the back of the book.

The second type of folders are green cardboard folders (ca. 58 preserved) with the hand-written title in the middle and a type of a com-

10 Source: the Collections Department of Auschwitz-Birkenau State Museum. 
position, which were written in black ink (Illustr. 3). In the upper-right corner, there was a name of a composer, and in the upper-left cornerthe catalogue number, written in red ink. In the majority of green folders, on the third inside hidden page the order form of the publishing house was pasted, ${ }^{11}$ in several cases filled in, containing information about a composer, title and the orchestral parts with empty verses on the right, left for writing the number (in the particular section of a table). Probably, this type of folders originates from the company which delivered the orders for the chapel in the main camp. ${ }^{12}$

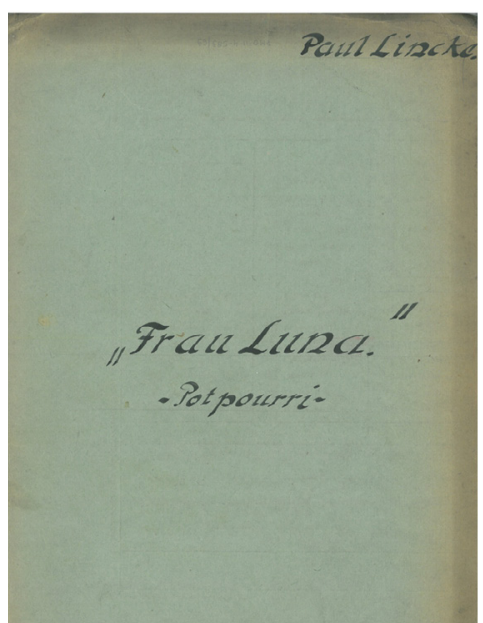

Illustr. 3: A green folder for scores. ${ }^{13}$

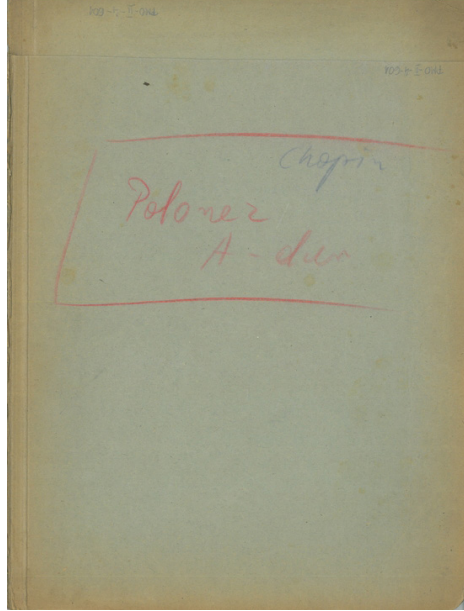

Illustr. 4: The inside page of a folder with a hand-written title written in red crayon and, above, a name of a composer sketched in pencil:

“Chopin / Polonez / A-dur".14

11 Mentioned order forms are pasted only in the green folders.

12 Jacek Lachendro cites the report of Henryk Król (Archive of the Auschwitz-Birkenau State Museum, The Statements Unit, vol. 76, pp. 204-205), who told that scores were delivered to the camp from the publishing house Breitkopf und Härtel in Leipzig (see: J. Lachendro, op. cit., p. 32). It is difficult to confirm this information. The research on the preserved sources shows that scores from many German and Italian publishing houses were used (see: Appx. III).

13 Source: the Collections Department of Auschwitz-Birkenau State Museum.

14 Source: ibid. 
The majority of discussed source materials originate from the period of activity of chapels in the camps of Auschwitz-Birkenau (1941-1945). The attempt to connect the preserved scores with the activity of of a precise chapel is particularly difficult. Jacek Lachendro says that the material kept in the Collection of the Auschwitz-Birkenau State Museum was used only by the orchestra of the main camp. Perhaps, it was the only "orchestra" (this term is used by the scholar $)^{15}$ in the Auschwitz-Birkenau camps that engaged a sufficient number of musicians to perform works kept in the collection at least comparatively accurately. However, we are not sure if these scores were used, arranged, re-written, and shared with the remaining chapels. ${ }^{16}$

It is worth mentioning that after war scores from the camps went a long way until they were obtained by the collection of the Museum in Auschwitz-Birkenau.After the evacuation of inmates, they were not left, as it could be assumed, in the area of the created later Museum in Oświęcim, but, similarly to the rest of post-Nazi belongings, in unclear circumstances were obtained by third party. These coincidences are presented by the report of Wiktor Zieliński, ${ }^{17}$ the former worker of Civic Militia, who secured post-camp belongings, submitted by the Soviet Army when leaving Poland. The author of a report claims that the submitting other belongings in accordance with the protocol was impossible, perhaps not only because of a huge amount of assets after former camp, but also because of the political situation of that time. Zieliński also sums up what he saw numerous times, when he was in the camp when the Soviet Army stayed there after the war:

15 The ensemble in the main camp (Auschwitz I) is the only one among the chapels existing in the camps of KL Auschwitz-Birkenau that can be correctly called the orchestra (a constant group of eighty people). The remaining ensembles should be examined as chapels of inmates (Häftlingskapelle), as this term includes different musicians participating and their practical function, or-less formallyLagerkapelle.

16 About the structure of the chapels see: ref. 2.

17 Archive of the Auschwitz-Birkenau State Museum, The Statements Unit, vol. 84, pp. $112-116$. 
[...] When it comes to the stolen belongings, partly obtained and displayed by the National Museum in Oświęcim, are with no doubt only leftovers of what I have seen in the warehouses-the buildings of the Lenin's colony nowadays, ${ }^{18}$ and what laid in the area around the camp. ${ }^{19}$

What happened to the objects from former Nazi camp, including scores and instruments, is described by the further words of the man:

\begin{abstract}
[...] I cannot explain if the houses stranded by German soldiers contained any paintings, sculptures or other object made by inmates. I cannot exclude this possibility. In the whole wide field of the former camp, there the objects left by inmates were laying, so here and there you could see a prisoner's clothes, a part of a soldier's uniform, work tool, or books and papers. Personally, I was not interested in this stuff. However, when I found the scores of different compositions, I took them, and it was several years after the war. These scores, a painting in oil, that the Soviet officer gave me, the sheet for the receipt of one of the German doctors, I leave for the National Museum in Oświęcim [...]. ${ }^{20}$
\end{abstract}

It is supposed that there were much more scores used in the KL Auschwitz-Birkenau than it may be assumed from the preserved ones. Thanks to the relations of the prisoners-musicians, we know that they took instruments with themselves during the evacuation of a camp. It could have been similar in the case of prints which had some market value. The fact that the marches and the similar music performed by the wind orchestra were not preserved can be probably explained by the fact that scores formerly belonging to the chapels of prisoners were next used by orchestras of the Soviet Army, which stayed in the area of the Oświęcim camps after the war. It cannot be excluded that local wind orchestras (including miners' orchestras) used these scores, when we take into consideration how many ensembles are in Oświęcim and in the neighbourhood and how reluctantly the postcamp belongings were secured, according to Zieliński.

18 Today the housing estate of Captain Witold Pilecki. The name was changed in 1991 from the initiative of the historian Adam Cyra.

19 Archive of the Auschwitz-Birkenau State Museum, The Statements Unit, vol. 84, pp. 115-116.

20 Ibid., p. 115. 
The first scores forwarded to the Museum in Oświęcim are dated on the year 1963. The further scores as well as instruments were forwarded in many stages. In years: 1963, 1967, 1971, 1973, 1975, 1983, 1989, $1993,1995,1997$, the first group of materials was collected, containing 85 objects. The second, greater, containing 144 objects, was bought in 2005 and 2006 by the Auschwitz-Birkenau State Museum. The scores were forwarded to the Collections Departament of the Museum together with the original folders, but their content was mixed. ${ }^{21}$ When archiving, the particular units were left in the order in which they were forwarded to the Museum. Because of that, the huge difficulty for research appears: to reconstruct the repertoire, it is necessary to arrange the material and to extract all the titles of works and names of composers-not only written on the prints and manuscripts, but also written on the folders and order forms of the publishing houses, absent in the preserved collection. The general outlook of the musical collection of the chapels of Auschwitz-Birkenau camps cannot be sketched until all the data is included (see: Appx. I).

\section{Preserved Musical Instruments}

The number of preserved musical instruments used by the chapels of prisoners in Auschwitz-Birkenau is very small, especially in comparison with the works of art, preserved in a significantly greater amount. ${ }^{22}$ Considering the number of performers only in the orchestra of the main camp, there were ca. 100 people in the culminating moment

21 It should be underlined that this "archival chaos" is not the Museum's fault. The author doubts as well if it could have been made by people who had kept the precious historical musical sources after the war, before they were forwarded to the collection. The mess could also have been a result of the fast securement of the post-camp belongings, and probably caring of them after the war. The author honestly believes that at that time the material was not orderly because of the fear that it could be damaged.

22 See: J. Kupiec, Cóż po nas zostanie...? Życie i twórczość więźnia obozu Auschwitz Mieczysława Kościelniaka, Oświęcim 2003; A. Sieradzka, Pozostawić po sobie ślad. Lekcja internetowa o sztuce w KL Auschwitz, Oświęcim 2016, [online] http://lekcja. auschwitz.org/pl_18_sztuka/ [accessed: 20.10.2016] (ibid.: the bibliography on the topic of the works of art in the Camp). 
of the camp's activity. Four preserved instruments ${ }^{23}$-all of them sent to the Collections Departament after the war-seem to be just a small part of the instruments of the chapels in Auschwitz-Birkenau. The high number in the catalogue of the preserved trumpet-"basy Beiny 158" (stamped on the attached badge)-lets us imagine how many musical instruments were used. It is known that the majority of the instruments belonged to the musicians-they were sent to the camp by families ${ }^{24}$ (at least at the beginning of the chapels' activity); less likely, the camp's authorities delivered them. It is unknown what happened to the two pianos, which Adam Kopyciński and Teodor Liese played at the time of the camp's activity ${ }^{25}$ (one of these instruments was fished out from the river Soła), as well as the piano belonging to the female chapel in Birkenau. ${ }^{26}$ We also do not know much about the music stands, taken, as Szymon Laks wrote, by the male Lagerkapelle in Birkenau after murdering the musicians from the Theresienstadt. ${ }^{27}$ The music stands are visible at least in the photos of the chapel in the main camp (Illustr. 5). Only one metal music stand is preserved; wooden stands could have been used as a fuel or destroyed as the time lapsed.

23 The detailed description of the preserved instruments is in the Appx. I.

24 See: Archive of the Auschwitz-Birkenau State Museum, The Statements Unit, vol. 96, pp. 16-21, the report of Franciszek Stryj; ibid., vol. 33, pp. 59-60, the report of Jan Baraniok; ibid., vol. 73, pp. 86-88, the report of Bolesław Majcherczyk.

25 See: I. Szczepański, Häftlingskapelle, Warszawa 1990, passim.

26 See: Sz. Laks, op. cit., p. 103.

27 "[...] Recently, in our neighbourhood the «Czech camp» was created, from Theresienstadt... They live together with wives and children, they still have long hair and old hairstyle, they do not work and get good food. They even have a small musical ensemble, consisting of over a dozen people [...]. And one day, suddenly we hear the horrible news. [...] The thing begins normally: from a long time, our music stands, rotten from frequent exposure to air and steeped in moisture, are almost impossible to use [...]. And then the crazy coincidence appears [...]. After a few days, the messenger arrives with a commission-I should immediately report to the commander together with certain musicians, but without instruments. We go there, intrigued [...]. «I heard that you need music stands. Take them. I organized them specially for your chapel.» We know these music stands. They are from the Czech camp, that we met once in business. Four thousand Czech people. We were envious of their carefree prosperity and last night they were burnt. [...] That was the price of our music stands [...]." Translation of a citation from: Sz. Laks, op. cit., pp. 93-94. 


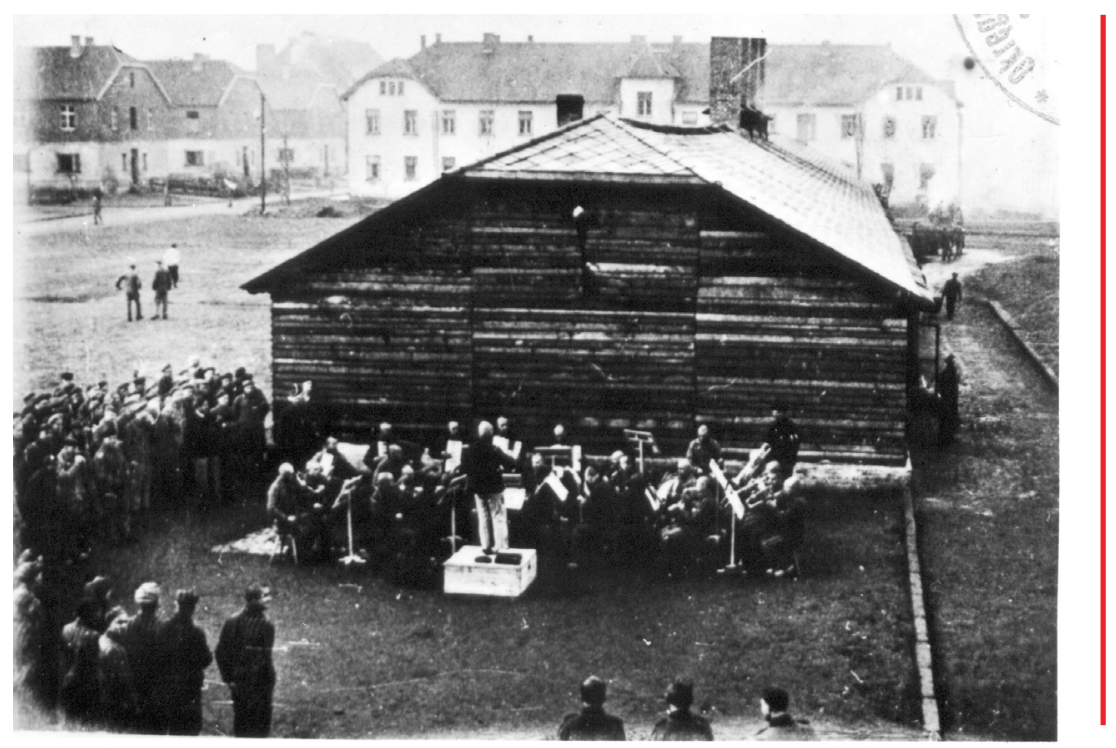

Illustr. 5: The photo of a chapel in front of a camp kitchen in $1942 .{ }^{28}$

28 Source: The Archive of the Auschwit-Birkenau State Museum, No. of neg. 337. The original photo is of very bad quality and very small. Below, I put the description made based on the large zoom.

In the foreground, the camp's chapel is visible, consisting of about 25 musicians. The chapel is playing in front of the camp kitchen building, near the gate. On the left side, there is a small group of listeners, set around the band. In the background on the left, there are prisoner blocks, in the central place, the block No. 25.

The chapel of the main camp is placed in the semi-circle. In the centre, the conductor is standing on a wooden platform (measuring approx. $50 \mathrm{~cm}$, estimated based on the legs of the music stands). On the podium behind the conductor, a folder (with notes?) is visible and an unidentified object-most likely a conductor's cap. On his left, violinists are sitting in the first and second line (about 5 people), followed by three accordionists (a clearly visible white keyboard on the right side of the instruments). In the middle and opposite to the conductor, there are instrumentalists, most of them difficult to identify, one playing the clarinet, and behind them probably two more accordionists. On the right side of the conductor in the first line, there are violinists or violists (4 people). There is an empty music stand behind them. The first of the musicians is keeping the instrument on the knee (he is not playing). In the second line, on the right side, there is a saxophonist, next to him a second musician, probably a trumpet player (in this place the image is overexposed). Behind him, there is a standing musician playing the percussion (probably a snare drum or similar, or some kind of bells). In the third, last line, there are two trumpet players and two trombonists, one of them holding the instrument directed upwards (he is not playing). Behind them, there is one more man, it is hard to tell if he is playing an instrument.

In the picture, it is possible to recognize about 10 wooden music stands. The prisoners are wearing striped uniforms (the most visible are the striped trousers of the conductor). The conductor is wearing a dark jacket. 


\section{The Classification of Preserved Scores}

As I have mentioned above, the musical sources kept in the Collections Departament of the Museum in Oświęcim were not listed according to the musical criteria but as archival units with catalogue numbers based on the date and the order in which they were forwarded to the Museum. Because of that, several works appear more than once with different catalogue numbers (namely, the score and parts of one composition does not always have the same catalogue number); the content of the folders not always match the titles of works, that are written on them; the same appears in the case of order forms. What is more, different works can be found in one catalogue number; they are often written by different composers, and in others we can find hand-written copies of orchestral parts of the works having different catalogue number in the print.

In terms of the orchestration, the material is diverse. The works intended for symphonic orchestra predominate, they are sometimes supplemented with instruments characteristic for a jazz band. In addition, there is a line of division between symphonic instrumental and vocal-instrumental works, usually with a solo voice, but also with larger vocal ensembles. Certainly, it cannot be assumed that the original form of scores was respected in the camp, because the number of voices and instruments were different in particular chapels. ${ }^{29}$ Works were arranged in accordance with the instruments that were available at the given moment, or not all parts were performed. It is unknown how the notes for piano were used (e.g. Adam Kopyciński's Lullaby that was preserved in the composer's manuscript, Koketterie by Erich Otto, Niagara by Carl Robrecht, Slawische Rhapsodie by Friedrich Wilhelm Rust) and for violin with piano accompaniment (Stücke Alter Meister published the Berlin publishing house Ad. Köster; Duets for violin and piano Op. 137 Nos. 1-3 by Franz Schubert, La Principessa

29 See: H. Dunicz-Niwińska, Drogi mojego życia. Wspomnienia skrzypaczki z Birkenau, Oświęcim 2013. The author underlines the huge differentiation of the instrumentation of the female chapel in Birkenau that was conducted by Alma Rosé. 
del Valzer by Luis Antonio Escobar) - apart from chamber music performed in the camp reality, perhaps they served as the basis for transcription into instrumental compositions, for instruments available at the time.

The group of symphonic works are the "constant repertoire", mostly from the 19th century, although the earlier ones are also present (Vivaldi, Handel, Haydn, Mozart, Beethoven, Weber, Berlioz, Grieg, Verdi, Puccini, Tchaikovsky, Rimsky-Korsakov and ChopinPolonaise in $A$ b in the orchestral version). Without exception, there are pieces that were present in the popular repertoire of the Germanspeaking area (in Germany, but also in Austria) immediately before the war. The same applies to a very large group of popular music works. It is mainly represented by fragments of popular operas and operettas (both Classical and newer ones, created in the interwar period). Then, they used overtures from well-known operas and operettas, arrangements of famous arias and dances, suites and potpourri that were fashionable at that time. The most popular were famous fragments from Franz von Suppés, Franz Lehár's, Johann Strauss's and Jacques Offenbach's operettas. In addition, the following names appear in this group: Heinrich Berté (1857-1924)—an Austro-Hungarian composer, a creator of six ballets and twelve operettas, ${ }^{30}$ Paul Lincke (1866-1946) - a German composer, an author of operettas, but also songs and marches, owner of the publishing house Apollo Verlag, which is a significant part of the repertoire preserved in the collections of Museum, ${ }^{31}$ E. Künnecke, E. MeyerHelmud, H. Steiner, W. Lautenschläger, J. Rixner, G. Winkler, E. Otto, H. Heumann, L. Siede and many more.

Another group, the greatest in terms of material preserved, is the arrangement of modern popular music (mainly well-known folk songs, e.g. Neapolitan song, hits from musicals, dance music and film music,

30 A. Lamb, Berté, Heinrich [Harry], [in:] Grove Music Online, [online] http://www.oxfordmusiconline.com/subscriber/article/grove/music/o2899 [accessed: 29.06.2016].

31 Ibid., the article: Lincke, (Carl Emil) Paul, [in:] Grove Music Online, [online] http://www. oxfordmusiconline.com/subscriber/article/grove/music/16669 [accessed: 29.06.2016]. 
see: Appx. III). The following names appear frequently here: Josef Rixner (1902-1973) - a German composer of popular music who lived in Berlin since 1932, ${ }^{32}$ Hans Ailbout (1879-1957)-a German composer of film and popular music, ${ }^{33}$ and composers who are totally unknown today: Otto Stolzenwald and Heinrich Steiner. Composers of film music included in the collection of the Museum are very difficult to identify today. The author managed to find information about Franz Grothe, who wrote music to about 167 films, but also arranged and wrote the extremely popular songs-hits; a close co-worker of Franz Lehár-Emmerich Kálmán, and Robert Stolz-influential figures of the German operetta scene of the first half of the 2oth century ${ }^{34}$ that directly influenced the later development of sound illustrations for initially silent films.

Particular attention should be paid to the presence in the repertoire of compositions by Paul Graener-a conductor and composer, political activist of the Nazi Party (from 1933), vice-president of Goebbels' Reichsmusikkammer and a successor of Richard Strauss at the prestigious position of the chief conductor in the National Socialist Party. ${ }^{35}$ The composer, as Erik Levi writes, ${ }^{36}$ does not have his own musical language, but only imitates the style created by R. Strauss, H. Pfitzner and M. Reger; as the composer, he was connected with the Zeitoper, popular at that time. There were more composers who organised the camp repertoire and simultaneously were known in Nazi Germany: for example, of course, Hitler's pupil,

32 Information about the composer from: Josef Rixner, [in:] Munzinger Online. Biographien, [online] https://www.munzinger.de/search/go/document.jsp?id=00000006582 [accessed: 31.03.2017].

33 Information about the composer from: Hans Ailbout, [in:] HeBu. Musikverlag GmbH, [online] https://www.munzinger.de/search/go/document.jsp?id=00000006582 [accessed: 31.03.2017].

34 I. Grünberg-Rinkleff, Grothe, Franz (Johannes August), [in:] Grove Music Online, [online] http://www.oxfordmusiconline.com/subscriber/article/grove/music/11836 [accessed: 29.06.2016].

35 E. Levi, Graener, Paul, [in:] Grove Music Online, [online] http://www.oxfordmusiconline.com/subscriber/article/grove/music/11578 [accessed: 29.06.2016].

36 Ibid. 
Richard Wagner, ${ }^{37}$ the creator of the Germanic national myth, as well as Franz Lehár.

What is outwardly surprising is the fact that the works written by Jewish composers were not eliminated from the camp repertoire, e.g. Antonio Vivaldi's compositions, who was a "representative Jew" in pseudo-musicological papers written by Nazi music theorists, such as Robert Passenlehner. ${ }^{38}$ On the basis of a quick research on German and Austrian concert repertoires and radio programs during the occupation, it can be seen that the implementation of racist directives into the practice of musical life was not an ubiquitous phenomenon in the centres managed by Nazi Germany. What creators of the programmes took into consideration was, first of all, the taste of the listeners, ${ }^{39}$ and those reported the demand for musical "hits", among which were also works by Jews: Strausses, Mendelssohn or just Vivaldi. The same applies to so-called U-Musik (Unterhaltungsmusik, popular music) and jazz songs (which were considered by the Nazis as a Jewish product). ${ }^{40}$ There was a huge social demand for them in the 1930s, they were released in large amounts, which probably made access to them during the war easier. The ideologues of the new culture of Nazi Germany, obviously, assumed that the "bad" musical culture should be replaced by a new one (a return to early and folk German music as well as a new sacred music were proposed here). ${ }^{41}$ It must be admit-

37 No words of Hitler himself were preserved on this topic, but many of his co-workers said something about this. For example, Hans Frank mentioned it in one of his conversations with an American psychiatrist Leon Goldensohn at the time of Nuremberg trials: "I am not attracted to Wagner-he said seriously-I have more classical taste. Führer had not a good taste. He liked Wagner's music because of pompous, teutonic splendor [...]." Transl. of a citation from: L. Goldensohn, Rozmowy norymberskie, transl. into Polish by D. Jankowska i A. Weseli-Ginter, Warszawa 2004, p. 55.

38 See: A. Tuchowski, Racjonalistyczne podstawy narodowosocjalistycznej refleksji o muzyce, [in:] idem, Nacjonalizm, szowinizm, rasizm a europejska refleksja o muzyce i twórczość kompozytorska okresu międzywojennego, Wrocław 2015, pp. $42-68$.

39 See: P.M. Potter, Die deutscheste der Künste. Musikwissenschaft und Gesellschaft von der Weimar Republik bis zum Ende des Dritten Reichs, Stuttgart 2000, p. 51.

40 Ibid., p. 23.

41 Ibid. 
ted, however, that this "upbringing" tendency did not appear in the actions of the authorities of the Auschwitz-Birkenau camp. One could define its musical repertoire as flattering fashion and commercial, if he would not be aware that musical productions of prisoners were by no means calculated for profit...

The participation of the most fashionable pieces of classical and popular music in the camp repertoire leads to the situation in which the majority of the compositions is cheerful in their character, frequently with the element of eroticism (in the case of operetta), humour and happiness. In these circumstances of hunger, pain, suffering, even the "animalisation" of a human ${ }^{42}$ - they were in huge contrast to the reality of a death camp and caused the musicophobia of inmates, that was mentioned numerous times in the post-war reports, mainly among those who were not interested in music before the war. The "ribald humour" ${ }^{43}$ emanating from the works played in the camp was,

42 J. Górniak, Jeszcze o muzyce w Oświęcimiu, "Ruch Muzyczny" 1946, No. 2, pp. 9-12. The author presents quite detailed psychological analysis of a prisoner, who-because of hunger, grogginess, and cold was "animalised", who loses the board between life and death and is obsessive about the fight for nourishment. The author pays special attention to the kind of a torture that music was in this situation-instead of listening to Beethoven's symphony, inmates would prefer to eat anything. After the war, in "Ruch Muzyczny" Górniak argues with Adam Kopyciński-the second conductor of the chapel in the main camp, who wrote about the musical activity in Auschwitz. See: A. Kopyciński, Orkiestra w oświęcimskim obozie koncentracyjnym, "Przegląd Lekarski" 1964, No. 1; idem, Ruch Muzyczny za drutami Oświęcimia, "Ruch Muzyczny" 1945 , No. 5 (answer to Górniak); idem, Skład orkiestry obozowej w Oświęcimiu, "Przegląd Lekarski" 1966, No. 1; his report in: I. Szczepański, op. cit., passim.

43 A. Siciński, Pieśń pomogła przetrwać. W 25. rocznicę oswobodzenia Oświęcimia, "Dziennik Ludowy" 1969, No. 22, p. 8 [copy in:] Archive of the Auschwitz-Birkenau State Museum, The Statements Unit, vol. 72, p. 182. The journalist in this text titled bravely Pieśń pomogła przetrwać - w 25. rocznicę oswobodzenia Oświęcimia (in English A song help us live-in the 25. Anniversary of releasing Oświęcim) tried to prove how huge role had played the resistance movement, namely the organization of the cultural life in the Oświęcim camp. He focused on the description of the private musical evenings and reading poetry by inmates in different blocks; he also described-as far as he remembered-the "huge camp orchestra". The author also mentions the short description of the program of official Sunday concerts for inmates, that took place next to the kitchen building, saying: "They were combined from maudlin and sentimental songs, magic tricks, mimic scenes and ribald humour..." It cannot be denied that the socialistic language and comparisons used by Siciński in cited text are shocking. 
as well, the reason for serious doubts of musicians concerning the moral aspect of performing music in the camp reality-numerous times, it helped the authorities manage the mass of people, tortured by hard work. Therefore, it should be underlined that executioners made the music a torture also for the group of inmates-prisoners who performed it.

\section{Music Composed in Auschwitz-Birkenau and Preserved in Manuscripts from the Sources of PMA-B}

In the collection of PMA-B there are compositions preserved that were composed by inmates during the time of existence of the AuschwitzBirkenau camps. Only three such compositions are preserved. The first of them is Buna-Lied, written by Anton Geppert and Fritz LöhnerBeda (prisoner number 68561) in Auschwitz III (Monowitz) on the 4th of December 1942. The first one is the author of music to the song, originally from Vienna; unfortunately, no other information about him was preserved. The second one is the author of text, a well-known writer and operetta librettist who collaborated with Franz Lehár, as well as an author of text to Das Buchenwaldlied composed at the end of 1938 with music by Hermann Leopoldi. ${ }^{44}$ The manuscript of BunaLied, as far the only one known source of this song, is probably only a copy. It is confirmed by the post-war service note written on the reverse (see: Appx. III).

44 Information about the writer from: B. Denscher, Fritz Löhner, [in:] Lexikon verfolgter Musiker und Musikerinnen der NS-Zeit, [online] https://www.lexm.uni-hamburg.de/object/lexm_lexmperson_00002627 [accessed: 31.03.2017]. Löhner strongly influenced the Viktor Frankl's analysis and his conception of logotherapy (a science of the sense of life). See: V. Frankl, Człowiek w poszukiwaniu sensu, transl. into Polish by A. Wolnicka, Warszawa 2008. 


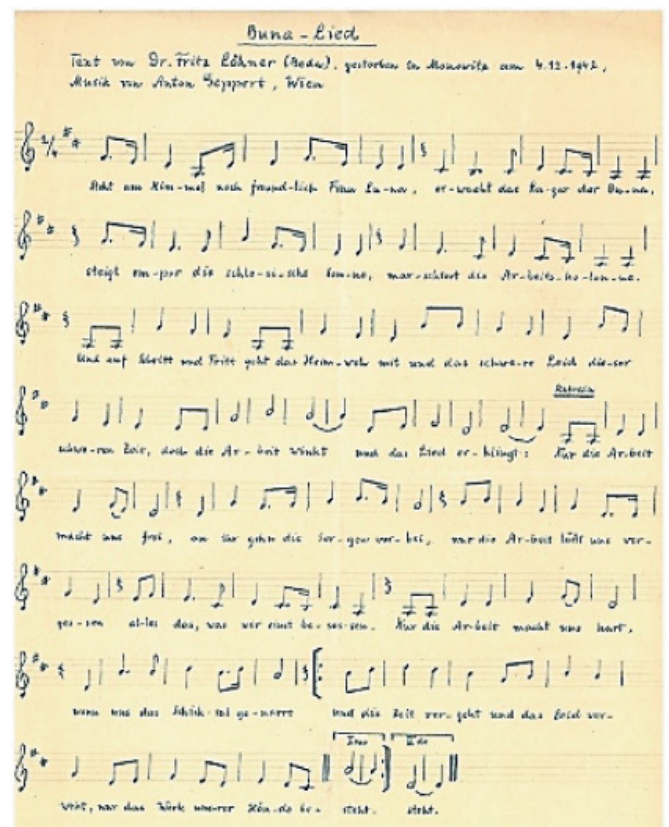

Illustr. 6: The manuscript of the song Buna-Lied. ${ }^{45}$

\section{Buna-Lied}

Steht am Himmel noch

freundlich Frau Luna, erwacht das Lager der Buna, steigt empor die schlesische Sonne, marchfest die Arbeitskolonne.

Und auf Schritt und Tritt geht das Heimweh mit und das schwere Leid dieser schweren Zeit, doch die Arbeit winkt und das Lied erklingt:

\section{Buna-Song} Still standing in the sky friendly Lady Luna, the Buna camp awakes, the Silesian sun rises, the working columns march on. And at every step homesickness goes with it and the great suffering of this hard time, but the work waits and the song sounds:

45 Source: The collection of PMA-B, cat. No. PMO-II-4-456. 
(Ref.)

Nur die Arbeit macht uns frei, an ihr gehn die Sorgen vorbei, nur die Arbeit läßt uns vergessen alles das, war wir einst besessen. Nur die Arbeit macht uns hart, wenn uns das Schicksal genarrt.

Und die Zeit vergeht

und das Leid verweht, nur das Werk unserer Hände besteht.
(Chorus:)

Only work makes us free it lets worries pass by, only the work lets us forget all that we were once obsessed with.

Only the work makes us hard, if fate fools us.

And time flies

and the suffering goes away, only the work of our hands remains.

The discussed song indicates strong connections with Buchenwaldlied, both in terms of content and the musical arrangement. In the only known source, which is a manuscript in the collection of PMA-B, there is one stanza of a text which says that only work makes prisoners free in the difficult camp reality, full of suffering and worries (it is worthy to mention that a wordplay appears: Frau Luna-Frau Buna; Frau Luna is a title of an operetta by Paul Lincke, very popular before the war; on the other hand, Buna is the title of a famous German synthetic rubber, produced before 1936). A song is based on the structure containing stanzas and chorus. At the end, voltas-typical for the song with stanzas-appear; the last phrase, containing a few bars, is repeated with the change of the ending notes. March-like rhythms are characteristic for Buna-Lied, as well as wide intervals: fourths, fifths, sixths, and even sevenths. The last one underlines the word "Schritt" ("step") in the phrase "und auf Schritt und Tritt geht das Heimweh mit" ("at every step homesickness goes with it"). Also the interval of sixth bolds the phrase: "wenn uns das Schicksal genarrt" ("if fate fools us"), making it the cry full of pain, intensified by the higher register, in comparison to the first part of a sentence, "nur die Arbeit macht uns hart" ("only work makes us hard"), that is in lower register. What is more, a fewbar progressions of the same musical material can be distinguished, 
that go together with the words "Heimweh" ("homesickness"), "Lied" ("song"), "schweren Zeit" ("hard time"). Before the chorus, the words set to the melody in half-notes, become more important, that are put in contrast to four-notes and eight-notes, dominating in the song, namely: "Arbeit winkt" ("work waits") and "Lied erklingt" ("song sounds"). This solution could have been introduced by the composer intentionally, in order to intensify the meaning of the key thoughts of the text-in this way, the composer left the time for breath for performers. Despite this, the musical shaping of Buna-Lied is not the simplest in terms of performance-mentioned intervals, wide vocal range ( $a-d^{2}$ or an octave below, when performed by male voices), as well as the combination of German prosody of a text with dotted rhythms could have been difficult to sing by the inmates, gaunt because of the hard work, hunger, heat or frost. As there is lack of reports talking about this song in a more detailed way, it cannot be said if it belonged to the real repertoire sang by all inmates. It is known that the executives of the camp (Auschwitz III) let prisoners sing the song officially, but only in German, what can suggest that Buna-Lied could have belonged to a common repertoire of a camp. Jerzy Strzelecki, a former inmate, mentions the other song in Polish, sang spontaneously, but discreetly by prisoners of Monowitz. Further, the man claims that he does not remember other songs concerning the commando Buna ${ }^{46}$ Because there is lack of source material made mainly by inmates-musicians, and preserved in the Archive of the Auschwitz-Birkenau State Museum, concerning Buna-Lied, the author

46 See: Archive of PMA-B, The Statements Unit, vol. 116, pp. 78-82, the relation made by Jerzy Strzelecki. The author claims in the statement, that inmates unofficially sang to the melody of a Polish military song Rozszumialy się wierzby płaczące the following words: “[...] Buna - sławne w obozie komando. Buna postrachem w całym lagrze jest. Lecz ten Bunę przeżyje zwycięsko, kto w lager Auschwitz krwawy przeszedł chrzest [...]". (In English: "[...] Buna-he is a famous commando in the camp. Buna-a terror in the whole camp. But one wins Buna if had a bloody baptism in Auschwitz [...]"). Strzelecki says that he does not know the author of the text of this song. Further he explains: "the song was sang spontaneously, probably it mirrored our mood. Obviously, we sang only when it was possible, when we were alone [...]. I do not remember if given song had other stanzas. I do not recollect to sing other songs, similar in meaning". 
postulates the special carefulness. It cannot be excluded that there is some information about this song in the relations to the inmates not connected with music, as the material was not precisely examined in this aspect.

The second preserved work is Lullaby (in Polish: Kolysanka) composed by Adam Kopyciński in the main camp in 1941, as evidenced by the detailed title dedication (see: Appx. II, No. 1). The piece is the expression of father's longing for a child caused by separation, so the work is very personal and intimate. In terms of music, the short Allegretto in a double metre is based on constantly repeated bass figurations in the left hand. On the contrary, the right hand plays seventh chords in inversions, grouped into small, two-bar thematic cells (then developed through rhythmic and textural ornamentation). In the middle part of a piece, the material of the right hand is presented in syncopation. In this fragment, three sound layers can be distinguished: the lower one with the bass figuration, the middle section with the melodic passages in seconds for the first beat in the bar, and the upper one, including the syncopated chords. In terms of dynamics, the composition is very varied, what intensifies the expression-during 41 bars, in which the work closes, there are as many as 16 dynamic remarks, from piano possibile to mezzo-forte.

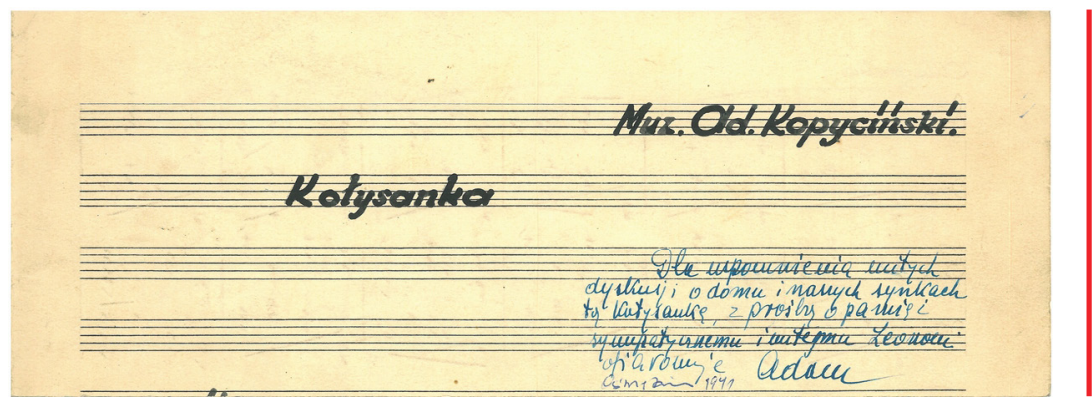

Illustr. 7: Adam Kopyciński, Kołysanka (manuscript)—a title with dedication. ${ }^{47}$

47 Source: the Collection of PMA-B, cat. No. PMO-II-4-425. 


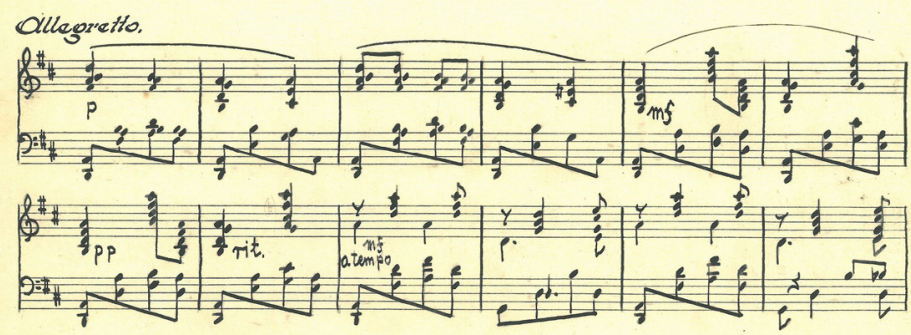

Illustr. 8: Adam Kopyciński, Kołysanka (manuscript)—two first staves from the score. ${ }^{48}$

From the last discussed work, Arbeitslager Marsch composed by the prisoner Henryk Król, only the cover has been preserved in the Collections Department of PMA-B (see: Appx. II, No. 2). The full manuscript was in possession of the composer, today it is probably already in the hands of his relatives. However, the Auschwitz-Birkenau State Museum has a photocopy of the composition. Seeing the work for the first time, the author of this article stated that this print is certainly not a manuscript from which the composition was performed while the camp existed. This is evidenced by the staff paper on which the march was written. This is most likely a music notebook produced by Polskie Wydawnictwo Muzyczne (Polish Music Publishing House)-in the bottom-left corner of the sheet, there is a matrix (WPM 14). This publishing house was created in 1945 . Hence, the described manuscript is a post-war attempt of the composer to reproduce the work performed in the main camp. A copy of this manuscript includes 26 cards. These are only instrumental parts (no score), intended for string quintet, flutes (2), oboes (2), clarinets (2), bassoons (2), French horns (4), trumpets (2), trombones (3), tube and snare drum. The march consists of two parts. The first, in $\mathrm{B} b$ major, begins with a seven-bar trumpet solo fanfare, followed by tutti. This part is dominated by a melodic movement based on arpeggiated chords, in the final section the solo part is played by flutes, clarinets and cellos. The middle part-Trio in Ab major-starts with secondary dominant to F minor key. In terms of a form, it can be presented with a scheme: 4 -bar introduction $+\mathrm{ABA}$. The introduction and the middle part $\mathrm{B}$ are maintained in the parallel key, and $\mathrm{A}$ and $\mathrm{A}^{\prime}$

$48 \quad$ Ibid. 
parts in the main key (Ab major) of this march. When analysing the rhythm, it can be noticed that in the whole work the tresillo patterns of four-notes and eight-notes are significant (often legato) when permanently accentuating the main impulse of a bar-a feature which is characteristic for the form of march. Lachendro claims ${ }^{49}$ that the composition is similar to Radetzky's March.

Despite the fact that the manuscript written in the camp is not preserved, Three Warsaw's Polonaises (Polish: Trzy polonezy Warszawskie) by Szymon Laks should be also mentioned. Actually, it is the arrangement of the polonaises by the unknown 18th-century author, a manuscript of which the composer found in Birkenau a short period of time after he became the Kapellmeister of the male chapel Auschwitz II. ${ }^{50}$ Unfortunately, during the research in the Collections Departament of the Auschwitz-Birkenau State Museum-where, as it can be assumed, the manuscript should be placed-the author of this article did not find any information about it. Perhaps, the manuscript of polonaises by an unknown author, found in Birkenau and cited by Laks in his memories, still exists, but it has not been forwarded to the Museum. Maybe somebody still has the arrangement of these polonaises, written by the hand of Szymon Laks, as well. Fortunately, the composer reconstructed Three Warsaw's Polonaises in 1947, and they were later published by PWM (Polish Music Publishing House). ${ }^{51}$

\section{Conclusion}

[...] I think it is my duty to make an attempt to explain and, in some way, immortalize this significant chapter of "history of music", which, perhaps, will be never studied by the professional historian of this branch of art. ${ }^{52}$

Ending this article, the above-quoted words of Szymon Laks-written at the end of his life-come to the author's mind. They picture the state of literature concerning the music in Auschwitz-Birkenau even in the

\footnotetext{
49 J. Lachendro, op. cit., p. 49.

50 Sz. Laks, op. cit., p. 67.

51 See: 3 polonezy warszawskie. Muzyka nieznanego autora $z$ XVIII wieku, arr. Sz. Laks, Kraków 1950.

52 Sz. Laks, op. cit., p. 10.
} 
1980s, especially in Poland. The present state of research concerning the discussed issue allow us to assume that the knowledge of the music written in these camps is gradually increasing, and, at the same time, it makes it possible to preserve the memory about the musical activity of the composers and musicians-performers, imprisoned there. However, the common knowledge of the subject becomes wider not so quickly. Because of that, in encyclopedias and lexicons, but also in the synthetic papers concerning history of music that have been published until the end of the 2oth century, this issue was not discussed at all. The article Holocaust Music appears only in The New Grove Dictionary of Music and Musicians, edited by Stanley Sadie ${ }^{53}$ and French encyclopedia Musiques. Une Encyclopédie pour le XX $X^{e}$ siècle, edited by Jean-Jacques Nattiez, has a whole chapter of the music in Nazi camps. ${ }^{54}$ Moreover, in 2006 Oxford University published the lexicon Music in the Holocaust. Confronting Life in the Nazi Ghettos and Camps. ${ }^{55}$

The vocal activity of inmates of Auschwitz-Birkenau has not been studied yet. Also, the precise confrontation of present research on Oświęcim's chapels with the knowledge of music performed in other Nazi camps becomes a challenge for the next generations of scholars. It is difficult to find the area of musicology that should analyse the musical activity in concentration camps, because this issue consists of many boarder fields-sociology of music, social psychology, psychology of music, music aesthetics ${ }^{56}$ and many other scientific disciplines. It proves the fact that the subject is complex, but also significant. The author hopes that this topic will be analysed in a complex way by a team of co-working experts from different scientific areas.

53 A. Knapp, Holocaust, [in:] The New Grove Dictionary of Music and Musicians, ed. S. Sadie, vol. 13, New York 2001, pp. 96-112.

54 J. J. Nattiez, M. Bent, R. Dalmonte, M. Baroni, Musiques. Une Encyclopédie pour le $X X^{e}$ siècle, vol. 1, Paris 2003.

55 G. Shirley, Music in the Holocaust. Confronting Life in the Nazi Ghettos and Camps, New York 2006.

56 More about the attempt to analyse this music from the social sciences' point of view, see: K. Naliwajek-Mazurek, The Functions of Music within the Nazi System of Genocide in Occupied Poland, [in:] W. Klimczyk, A. Swierzowska, Music and Genocide, series «Studies in Social Sciences, Philosophy and History of Ideas», vol. 9, Frankfurt am Main 2015. 


\section{Appx. I: Instruments and musical accessories kept in the Collections Departament of PMA-B}

\section{Clarinet in $\mathbf{B}$,}

\section{Cat. No.: PMO-II-4-179}

Short description: The instrument from the chapels of Auschwitz I and III (Monowitz). Description under the mouthpiece: "Made in Czechoslovakia / Amati Toneking". The number "232" on the barrel is a number of the instrument in the camp orchestra (information in the catalogue cart) or the number given by the producer. Lack of the original case. The instrument belonged to the inmate Ignacy Stopka (Prisoner No. 86261), who played in the orchestra of the main camp since March 1943 and who was moved to Monowitz (Auschwitz III) on September of the same year. Stopka took the clarinet with himself during the evacuation of a camp. Then, he was taken to the camp Nordhausen-Dora, and released in the camp Bergen-Belsen. Coming back to Poland, he took that clarinet with himself. He said that the instrument had belonged to his friend Dulin, who died in the camp.

Bibliography: Archive of PMA-B, The Statements Unit, vol. 45, pp. 13-115, 121, the report of Ignacy Stopka.

\section{Violin}

Cat. No.: PMO-II-4-314

Short description: The instrument from the chapel of Auschwitz I, together with the bow and case. Made probably in the second half of the 19th or at the beginning of the 2oth century. Inside the instrument (under F holes) the sticker with two round seals, on which there is a description "Fabrik Marke"; between them dusty, impossible to read, hand-written description (probably the number of production). A pag moved right. Strings loose. A scroll with ornamentation. The round badge with stamped number " 27 ", attached with wire to the neck. The number is also the catalogue number of the instrument in the camp orchestra, and in this case, another number of the orchestra player. A cardboard case, with black bookbinding canvas on top. The handle of a case is a holder from the leather belt. Moreover, in 
the cupboard inside the case, there are two supports, one smaller with the description "VUILLAUME", and a bow with hair removed from the frog. The instrument should be investigated by the specialist luthier in order to prepare a detailed description and make further indications concerning its conservation and storage.

The violin belonged to Franciszek Stryj (Prisoner No. 11091), who was arrested by Gestapo in Zabrze in March 1941, then transported to Auschwitz on the 25th of March 1941. Stryj described how Józef Biasecki (bass player) was defeated by Franz Nierychło-the first conductor of the main camp. The violinist went to express his compassion to the bassist, who, in exchange, helped him to be invited to the orchestra. To pass the exam to the orchestra, the wrote a letter to home with request to send him violin. His wife went to Oświęcim and there she sent the instrument, to make the way shorter. The instrument arrived in the deplorable condition - broken bridge, broken string, out of tune. Adam Wysocki-the host of a music hall-repaired it. Stryj played it during the exam with Nierychło, who gave him an overture to operetta Dichter und Bauer (by Franz von Suppé) and the march Salve imperator (probably by Julius Fučík) to play a vista. The previous owner of the instrument was the father of Stryj. The young violinist played in the chapel of Auschwitz I only until July 1941, then he contracted typhus. He was to be forwarded for the trial next to Sondergericht and sent to another prison. His personal belongings, including the violin, took his father. After the war, F. Stryj sent his instrument to the Collections Department of PMA-B.

Bibliography: Archive of PMA-B, The Statements Unit, vol. 96, pp. 16-21, the report of Franciszek Stryj.

\section{Accordion}

\section{Cat. No.: PMO-II-4-441}

Short description: The instrument made by the brand "Sovereign" with 120 basses, in black case. In the camp, Jan Baraniok (Prisoner No. 7649) played it. In the catalogue card, there is information that the instrument was sent to the camp by the prisoner's parents, but Baraniok himself says 
in his report that there were a few accordions at that time found, bought by the camp authorities from the inmates' money. The musician was arrested on the 18th of December 1940, and the same day he was transported to Auschwitz. He underlined that he was a pianist and that playing for inmates with functions saved his life. Then, in his report, he makes detailed report about the fact of creating chapels in the main camps. There is lack of information about what happened to the instrument later.

Bibliography: Archive of PMA-B, The Statements Unit, vol. 96, pp. 16-21, the report of Jerzy Baraniok (stamped on a small badge).

\section{Bass tuba-“basy Beiny"}

\section{Cat. No.: PMO-II-4-495}

Short description: On the instrument, there is description stamped: "Otto Singer Desau". The instrument belonged to the inmate Bolesław Majcherczyk (Prisoner No. 24913), who played trumpet in chapel of the main camp Auschwitz I and in the camp Bergen-Belsen. His friend, Sapiński, wrote a letter to the family on his behalf with request to send the instrument from home. The instrument received number "158" (stamped on a small badge). Majcherczyk was able to take the instrument with him during evacuation and transport to KL BergenBelsen. Then, he was transported to KL Dora, where he still played in the orchestra on this instrument. In 1989, Bolesław Majcherczyk gave the instrument to the Department of Collections PMA-B.

Bibliography: Archive of PMA-B, The Statements Unit, vol. 73, pp. 86-88, the report of Bolesław Majcherczyk.

\section{Music stand}

Cat. No.: PMO-II-4-429

Short description: on the catalogue card, a description "stojak na nuty" ("music stand"). A fragment of destroyed music stand. Lack of the base, only a fragment of a leg. Lack of information, to which chapel the music stand belonged. 


\section{Appx. II: Compositions written in KL Auschwitz-Birkenau- manuscripts preserved in the Departament of Collections of PMA-B}

\section{Title: Kolysanka (in English: Lullaby)}

\section{Author: Adam Kopyciński}

Cat. No.: PMO-II-4-425

Short description: The manuscript on staff paper; size: 3 pages (3 staffs cut from the one sheet of paper-Beethoven Papier No. 33[16 Linen]). On the first page, a hand-written dedication: "Muz. Ad. Kopyciński. / Kołysanka / Dla wspomnienia miłych dyskusji o domu i naszych synkach tą kołysankę, z prośbą o pamięć sympatycznemu i miłemu Leonowi ofiarowuje Adam / Oświęcim 1941" (in English: "Mus. Ad. Kopyciński / Lullaby / For the memories of nice discussions about home and our sons, I dedicate this lullaby to the lovely and nice Leon with request for memory-Adam / Oświęcim 1941").

\section{Title: Arbeitslager / Marsch / Heinrich Krol}

Author: Henryk Król

Cat. No.: PMO-II-4-198

Short description: White cover from the score of the march Arbeitslagermarsch. A title hand-written in black ink, under the title drew lire and rose's leaves. Below, the name of the composer in German. The work composed in 1941 by Henryk Król (Prisoner No. 1183). Complete work (manuscript, parts, lack of a score) belongs to the author's family.

\section{Title: Buna-Lied}

Author: music - Anton Geppert, text - Fritz Löhner

Cat. No.: PMO-II-4-456

Short description: A manuscript of a song sang in KL Monowitz (Auschwitz III). Below the description: “Text von Dr. Fritz Löhner 
(Beda), gestorben in Monowitz am 4.12.1942. / Musik von Anton Geppert, Wien". The manuscript consists of eight staffs with music notation and text under it (1 card). On the reverse of the manuscript, below-right located, there is hand-written description in pencil: "Bausch podziękować dla Zw w Austrii Danimann” (in English: Bausch thank [sic!] for Zw in Austria Danimann"), that is a post-war annotation made by the worker of PMA-B, probably J.A. Brandhuber.

\section{Appx. III: Remaining preserved works (musical prints), kept in the Department of Collections of PMA-B}

\section{a) Identified compositions}

Below, there are the sources shown chronologically according to the authors' date of birth. Moreover, to make the text clearer, the catalogue numbers in the Department of Collections of the Auschwitz-Birkenau State Museum are provided; (T) - a folder in which the title of a work is written (not always equal with the content); (ZW)-order form of a publishing house, glued into green folders, on which the title is written, sometimes together with orchestral parts; (KRG) - a manuscript copy of orchestral parts, performed by inmates-copyists from the musical prints; (R)-manuscript; (D) - musical print, the sign appears only in the doubtful cases; if any of given signs appears next to the work-it is also a musical print.

\begin{tabular}{|l|l|}
\hline $\begin{array}{l}\text { Antonio Vivaldi } \\
(1678-1741)\end{array}$ & $\begin{array}{l}\text { Concerto la mineur pour } 2 \text { Violons in A minor, Orchestre à } \\
\text { cordes et orgue ou 2 Violons et Piano, RV } 522 \text { [PMO-II-4-185] }\end{array}$ \\
\hline $\begin{array}{l}\text { Georg Friedrich } \\
\text { Händel } \\
(1685-1759)\end{array}$ & $\begin{array}{l}\text { Stücke Alter Meister / für / Violine und Klavier / Fortsetzung } \\
\text { / der von Willy Burmester begonnen Sammlung / Neu } \\
\text { bearbeitet von / Gustav Hollander / No. 41 Händel } \\
\text { Sarabande, pub. Ad. Köster, Berlin [PMO-II-4-186/1,2] } \\
\text { Largo / Aria aus der Oper: Xerxes [PMO-II-4-630/14 (T)] }\end{array}$ \\
\hline
\end{tabular}




\begin{tabular}{|c|c|}
\hline $\begin{array}{l}\text { Johann Sebastian Bach } \\
(1685-1750)\end{array}$ & $\begin{array}{l}\text { Stücke Alter Meister / für / Violine und Klavier / Fortsetzung } \\
\text { / der von Willy Burmester begonnen Sammlung / Neu } \\
\text { bearbeitet von / Gustav Hollander / No. } 38 \text { Bach Bourrée, } \\
\text { pub. Ad. Köster, Berlin [PMO-II-4-186/1,2] }\end{array}$ \\
\hline $\begin{array}{l}\text { Joseph Haydn } \\
(1732-1809)\end{array}$ & $\begin{array}{l}\text { Symphonien für Pianoforte zu } 4 \text { Händen, Band I, No. 125I, } \\
\text { pub. B\&H, Leipzig. [Cat. No. PMO-II-4-460] } \\
\text { Stücke Alter Meister / für / Violine und Klavier / Fortsetzung } \\
\text { / der von Willy Burmester begonnen Sammlung / Neu } \\
\text { bearbeitet von / Gustav Hollander / No. } 39 \text { No. } 40 \text { Haydn } \\
\text { Capriccio, pub. Ad. Köster, Berlin [PMO-II-4-186/1,2] } \\
\text { Symphonie mit dem Paukens [PMO-II-4-583/68 (ZW)] }\end{array}$ \\
\hline $\begin{array}{l}\text { Friedrich Wilhelm Rust } \\
(1739-1796)\end{array}$ & $\begin{array}{l}\text { Chinesischer Teehändler / Scène caractéristique, arr. } \\
\text { Hartwig von Platen, pub. Richard Birnbach, Berlin. [PMO- } \\
\text { II-4-583/30 (Cat. No. PMO-II-4-583/30: T)] } \\
\text { Slawische Rhapsodie, arr. Hartwig von Platen, pub. Richard } \\
\text { Birnbach, Berlin [PMO-II-4-583/6] } \\
\text { Slawische Rhapsodie / Klavier-Cadenz, piano cadence } \\
\text { to Rapsodia above, written by one of inmates (signature } \\
\text { impossible to read) [PMO-II-4-596 (R-2 k.)] } \\
\text { Schwabenmädel / Walzer, arr. Hartwig von Platen, pub. } \\
\text { Richard Birnbach, Berlin [PMO-II-4-583/43] } \\
\text { Kleine Ouverture / Lachendes leben [PMO-II-4-583/64 } \\
\text { (ZW)] } \\
\text { Fantasie für jazzorchester Colibri [PMO-II-4-382 (ZW)] }\end{array}$ \\
\hline $\begin{array}{l}\text { Wolfgang Amadeus } \\
\text { Mozart } \\
(1756-1791)\end{array}$ & $\begin{array}{l}\text { Sinfonie D-dur (mit Menuett) KV 385, pub. Otto Wrede } \\
\text { Regina Verlag, Berlin [PMO-II-4-367] } \\
\text { Die Zauberflöte - Ouvertüre, pub. B\&H, Leipzig [PMO- } \\
\text { II-4-195] } \\
\text { Die Entführung aus dem Serail - Ouvertüre KV 384, pub. } \\
\text { B\&H, Leipzig [PMO-II-4-349 (Cat. No. PMO-II-4-583/59: ZW)] } \\
\text { Stücke Alter Meister / für / Violine und Klavier / Fortsetzung } \\
\text { / der von Willy Burmester begonnen Sammlung / Neu } \\
\text { bearbeitet von / Gustav Hollander / No. } 39 \text { Mozart Gavotte, } \\
\text { pub. Ad. Köster, Berlin [PMO-II-4-186/1,2] }\end{array}$ \\
\hline $\begin{array}{l}\text { Luigi Cherubini } \\
(1760-1842)\end{array}$ & Die Abenceragen - Oüverture [PMO-II-4-378: ZW] \\
\hline
\end{tabular}




\begin{tabular}{|c|c|}
\hline $\begin{array}{l}\text { Ludwig } \\
\text { van Beethoven } \\
(1770-1827)\end{array}$ & $\begin{array}{l}\text { V Symfonia c-moll Op. 67, pub. B\&H, Leipzig [PMO-II-4-180 } \\
\text { (Cat. No. PMO-II-4-391: T)] } \\
\text { Stücke Alter Meister / für / Violine und Klavier / Fortsetzung } \\
\text { / der von Willy Burmester begonnen Sammlung / Neu } \\
\text { bearbeitet von / Gustav Hollander / No. } 37 \text { Beethoven } \\
\text { Contretanz, pub. Ad. Köster, Berlin [PMO-II-4-186/1,2] } \\
\text { Klavier-Konzert... Nr } 5 \text { [PMO-II-4-389: ZW] }\end{array}$ \\
\hline $\begin{array}{l}\text { Johann Baptist Cramer } \\
(1771-1858)\end{array}$ & $\begin{array}{l}\text { Stücke Alter Meister / für / Violine und Klavier / Fortsetzung } \\
\text { / der von Willy Burmester begonnen Sammlung / Neu } \\
\text { bearbeitet von / Gustav Hollander / No. } 42 \text { Cramer Walzer, } \\
\text { pub. Ad. Köster, Berlin [PMO-II-4-186/1,2] }\end{array}$ \\
\hline $\begin{array}{l}\text { Carl Maria von Weber } \\
(1786-1826)\end{array}$ & $\begin{array}{l}\text { Jubel - Ouvertüre, pub. Verlag von Anton J. Benjamin, } \\
\text { Hamburg-Leipzig-Mailand [PMO-II-4-583/4] } \\
\text { Beherrscher der Geister - Ouvertüre [PMO-II-4-610: ZW] }\end{array}$ \\
\hline $\begin{array}{l}\text { Franz Schubert } \\
(1797-1828)\end{array}$ & $\begin{array}{l}\text { Duos für Pianoforte und Violine Op. } 137 \text { No. 1-3, pub. } \\
\text { Edition Peters, Leipzig [PMO-II-4-184] }\end{array}$ \\
\hline $\begin{array}{l}\text { Hector Berlioz } \\
(1803-1869)\end{array}$ & $\begin{array}{l}\text { Le Carnaval Romain - Ouverture caractéristique, arr. Henry } \\
\text { Weber, pub. Edition Cranz (Lack of place of publishing) } \\
\text { [PMO-II-4-583/57 (Cat. No. PMO-II-4-630/21: T)] }\end{array}$ \\
\hline $\begin{array}{l}\text { Fryderyk Chopin } \\
(1810-1849)\end{array}$ & Polonez / A Major [PMO-II-4-601: T] \\
\hline $\begin{array}{l}\text { Friedrich von Flotow } \\
(1812-1883)\end{array}$ & $\begin{array}{l}\text { Ouvertüre zur Oper: / Martha / No. 1, arr. L. Weninger [PMO- } \\
\text { II-4-583/81] }\end{array}$ \\
\hline $\begin{array}{l}\text { Richard Wagner } \\
(1813-1883)\end{array}$ & $\begin{array}{l}\text { Erinnerung an Richard Wagners Rienzi, arr. Otto Hohmann, } \\
\text { pub. Anton J. Benjamin Musikverlag, Leipzig-Milano [PMO- } \\
\text { II-4-583/1] } \\
\text { Erinnerung an Richard Wagners Lohengrin, arr. Otto } \\
\text { Hohmann, pub. J. Anton, J. Benjamin, Hamburg [PMO- } \\
\text { II-4-618] } \\
\text { Wagners Heldenbuch / Fantasie, arr. Ernst Urbach, pub. } \\
\text { Otto Wrede Regina-Verlag, Berlin [PMO-II-4-602] } \\
\text { Das Liebesmahl der Apostel [PMO-II-4-392: T] } \\
\text { Kleine Fantasie über R. Wagners / Lohengrin, arr. Fr. Eberle } \\
\text { [PMO-II-4-583/72: ZW] }\end{array}$ \\
\hline $\begin{array}{l}\text { Giuseppe Verdi } \\
(1813-1901)\end{array}$ & $\begin{array}{l}\text { Rigoletto - Fantasie Sélection, arr. Leopold Weninger, pub. } \\
\text { D. Räder, Leipzig [PMO-II-4-583/19, PMO-II-4-630/20, PMO- } \\
\text { II-4-597: KRG: Sax. B] } \\
\text { Un ballo in maschera / Potpourri, arr. Rich. Atzler, pub. } \\
\text { August Cranz, Leipzig [PMO-II-4-605] }\end{array}$ \\
\hline
\end{tabular}




\begin{tabular}{|c|c|}
\hline $\begin{array}{l}\text { Jacques Offenbach } \\
(1819-1880)\end{array}$ & $\begin{array}{l}\text { La belle Helene / Fantasie, arr. Rich. Atzler, pub. Edition } \\
\text { Cranz, Leipzig [PMO-II-4-583/73] }\end{array}$ \\
\hline $\begin{array}{l}\text { Franz von Suppé } \\
(1819-1895)\end{array}$ & $\begin{array}{l}\text { Fantasie aus der Operette: / Fatinitza, arr. Rich. Atzler, pub. } \\
\text { Edition Cranz, Leipzig [PMO-II-4-583/73 (Cat. No. PMO- } \\
\text { II-4-630/24: T; PMO-II-4-394 - ZW) } \\
\text { Die schöne Galathe / Potpourri aus der komischen Operette } \\
\text { (lack of inf. About the author of the arrangement), pub. Aug. } \\
\text { Cranz GmbH., Leipzig [PMO-II-4-583/58] } \\
\text { Zehn Mädchen und kein Mann / Ouverture zur komischen } \\
\text { Oper, arr. Rich. Atzler, pub. Edition Cranz, Leipzig [PMO- } \\
\text { II-4-583/60] } \\
\text { Ein Wiener Souper / Fantasie / über /Suppé'sche Melodien, } \\
\text { arr. Victor Hruby, pub. Edition-Cranz, Leipzig [PMO- } \\
\text { II-4-191/1-3] } \\
\text { Das ist mein Oesterreich, pub. Verlag Anton J. Benjamin, } \\
\text { Leipzig-Milano [PMO-II-4-464: D and KRG] }\end{array}$ \\
\hline $\begin{array}{l}\text { Édouard Lalo } \\
(1823-1892)\end{array}$ & $\begin{array}{l}\text { Ouvertüre zur Oper Le Roi d'Ys, arr. E. Haensch [PMO- } \\
\text { II-4-461] }\end{array}$ \\
\hline $\begin{array}{l}\text { Johann Strauss } \\
(1825-1899)\end{array}$ & $\begin{array}{l}\text { Potpourri aus: / Das Spitzentuch der Königin, arr. Henry } \\
\text { Weber, pub. Aug. Cranz, GmbH., Leipzig [PMO-II-4-583/71] } \\
\text { Potpourri aus der Operette / Ein Nacht in Venedig, arr. } \\
\text { Henry Weber, pub. Aug. Cranz, GmbH., Leipzig [PMO- } \\
\text { II-4-583/74] } \\
\text { Potpourri aus der Operette: / } 1001 \text { Nacht, arr. Henry Weber, } \\
\text { pub. Aug. Cranz, GmbH., Leipzig [PMO-II-4-630/1] } \\
\text { Der Karneval in Rom - Ouvertüre [PMO-II-4-583/66: T] }\end{array}$ \\
\hline $\begin{array}{l}\text { August Lanner } \\
(1835-1855)\end{array}$ & $\begin{array}{l}\text { Die erste Gedanken, arr. Erich Frost, pub. Edition Cranz, } \\
\text { Leipzig [PMO-II-4-583/69] }\end{array}$ \\
\hline $\begin{array}{l}\text { Piotr Iljicz Czajkowski } \\
(1840-1893)\end{array}$ & $\begin{array}{l}\text { Peter Tschaikowsky - Konzert-Suite / (in } 4 \text { Sätzen), arr. Josef } \\
\text { Németi, pub. Kistner \& Siegel, Leipzig [PMO-II-4-583/11 (Cat. } \\
\text { No. PMO-II-4-583/67: T)] } \\
\text { Eugen Onegin / Grosse Fantasie [PMO-II-4-583/62: T] }\end{array}$ \\
\hline $\begin{array}{l}\text { Alphons Czibulka } \\
(1842-1894)\end{array}$ & $\begin{array}{l}\text { Gavotte - Stephanie op. 312, arr. L. Artok, pub. B. Schotts } \\
\text { Söhne, Mainz [PMO-II-4-583/76, PMO-II-4-630/21] }\end{array}$ \\
\hline $\begin{array}{l}\text { Jules Massenet } \\
(1842-1912)\end{array}$ & $\begin{array}{l}\text { Scénes Dramatiques - Prélude, arr. L. Artok, pub. B. Schotts } \\
\text { Söhne, Mainz [PMO-II-4-583/17] }\end{array}$ \\
\hline
\end{tabular}




\begin{tabular}{|c|c|}
\hline $\begin{array}{l}\text { Edward Grieg } \\
(1843-1907)\end{array}$ & $\begin{array}{l}\text { Am der Frühling op. } 43 \text { No. 6, arr. Gottfr. Huppertz, pub. C.F. } \\
\text { Peters, Leipzig [PMO-II-4-583/40] } \\
\text { Peer Gynt Suite I op. 46, arr. L. Weninger, pub. C.F. Peters, } \\
\text { Leipzig [PMO-II-4-189/1-44 (Cat. No. PMO-II-4-583/67: ZW)]. } \\
\text { Peer Gynt Suite II op. 55, arr. L. Weninger, pub. C.F. Peters, } \\
\text { Leipzig [PMO-II-4-630/18, PMO-II-4-630/22] } \\
\text { Erotik / Poème érotique op. } 43 \text { No. 5, arr. Gottfr. Huppertz, } \\
\text { pub. C.F. Peters, Leipzig [PMO-II-4-583/22] }\end{array}$ \\
\hline $\begin{array}{l}\text { Carl Michael Ziehrer } \\
(1843-1922)\end{array}$ & $\begin{array}{l}\text { Ouvertüre / zur der Operette Die Landstreicher, arr. Josef } \\
\text { Stumpf, pub. Ludwig Doblinger, Wien-Berlin-Leipzig [PMO- } \\
\text { II-4-630/3] } \\
\text { Der Zauber der Montur Marsch [PMO-II-4-386: ZW] } \\
\text { Unanfechtbar Marsch [PMO-II-4-386: ZW] }\end{array}$ \\
\hline $\begin{array}{l}\text { Nikołaj Andriejewicz } \\
\text { Rimski-Korsakow } \\
\text { (1844-1908) }\end{array}$ & $\begin{array}{l}\text { Capriccio Espagnol op. 34, transcribed by Th. Hartmann, } \\
\text { pub. M.P. Belaieff, Leipzig [PMO-II-4-183] }\end{array}$ \\
\hline $\begin{array}{l}\text { Richard Eilenberg } \\
(1848-1927)\end{array}$ & $\begin{array}{l}\text { Schwarzwald Ein Idyll op. 52/ Le moulin de la forêt noire } \\
\text { [PMO-II-4-188/1-14] }\end{array}$ \\
\hline $\begin{array}{l}\text { Karel Komzák } \\
(1850-1905)\end{array}$ & $\begin{array}{l}\text { Neue Wiener Volksmusik / Potpourri, pub. Julius Chmel } \\
\text { [PMO-II-4-583/20] } \\
\text { Echtes Wienerblut [PMO-II-4-385: ZW] }\end{array}$ \\
\hline $\begin{array}{l}\text { Karl Wilhelm Drescher } \\
(1850-1925)\end{array}$ & Linzer Nuam / Marsch [PMO-II-4-630/15: ZW] \\
\hline $\begin{array}{l}\text { Robert Vollstedt } \\
\text { (1854-1919) }\end{array}$ & $\begin{array}{l}\text { Japanische Wachtparade Op. 92, pub. Aug. Cranz, Hamburg } \\
\text { [PMO-II-4-583/38 (Cat. No. PMO-II-4-593: KRG)] }\end{array}$ \\
\hline $\begin{array}{l}\text { Engelbert } \\
\text { Humperdinck } \\
(1854-1921)\end{array}$ & Vorspiel / Hänsel und Grettel [PMO-II-4-583/53: ZW] \\
\hline $\begin{array}{l}\text { Oskar Fetrás } \\
(1854-1931)\end{array}$ & $\begin{array}{l}\text { Tirol in Lied und Tanz / Divertissement Op. 139, pub. Anton } \\
\text { J. Benjamin, Leipzig [PMO-II-4-583/70] } \\
\text { Schleswig-Holstein / Marsch [PMO-II-4-601: ZW] }\end{array}$ \\
\hline $\begin{array}{l}\text { Heinrich Berté } \\
(1858-1924)\end{array}$ & $\begin{array}{l}\text { Großes Potpourri / nach Motiven des Singspieles: Das } \\
\text { Dreimäderlhaus, instr. Martin Uhl, pub. Ludwig Doblinger, } \\
\text { Wien-München [PMO-II-4-609] }\end{array}$ \\
\hline $\begin{array}{l}\text { Giacomo Puccini } \\
(1858-1924)\end{array}$ & $\begin{array}{l}\text { Große Fantasie aus der Oper: / La Bohéme / No. } 310 \text { [PMO- } \\
\text { II-4-196] }\end{array}$ \\
\hline $\begin{array}{l}\text { Emil von Reznicek } \\
(1860-1945)\end{array}$ & $\begin{array}{l}\text { Ouvertüre zur Oper Donna Diana, arr. B. Leopold, pub. } \\
\text { Universal Edition, Wien-Leipzig [PMO-II-4-583/14] }\end{array}$ \\
\hline
\end{tabular}




\begin{tabular}{|c|c|}
\hline $\begin{array}{l}\text { Erik Meyer-Helmund } \\
(1861-1932)\end{array}$ & $\begin{array}{l}\text { Sérénade-Roccoco, pub. Bosworth u. Co., London-Leipzig- } \\
\text { Wien-Bruxelles [PMO-II-4-583/54] }\end{array}$ \\
\hline $\begin{array}{l}\text { Franz von Blon } \\
(1861-1945)\end{array}$ & $\begin{array}{l}\text { Frauen-Liebe und Leben / Walzer, arr. Fr. Schimak, pub. Otto } \\
\text { Wernthal, Berlin [PMO-II-4-630/19] }\end{array}$ \\
\hline $\begin{array}{l}\text { Richard Strauss } \\
(1864-1949)\end{array}$ & $\begin{array}{l}\text { Morgen op. } 27 \text { No. 4, arr. Arnold Wilke, pub. Universal } \\
\text { Edition, Wien-Leipzig [PMO-II-4-585] }\end{array}$ \\
\hline $\begin{array}{l}\text { Otto Kockert } \\
(1865-1941)\end{array}$ & $\begin{array}{l}\text { Der Kleine Pfiffikus op. 98, arr. Carl Zimmer, pub. Richard } \\
\text { Birnbach, Berlin [PMO-II-4-586] } \\
\text { Intermezzo / Einzug der Frühlingsblumen [PMO- } \\
\text { II-4-583/56: T] }\end{array}$ \\
\hline $\begin{array}{l}\text { Paul Lincke } \\
\text { (1866-1946) }\end{array}$ & $\begin{array}{l}\text { Lasst den Kopf nicht hängen! / Grosses Potpourri, pub. } \\
\text { Apollo Verlag, Berlin [PMO-II-4-630/5] } \\
\text { Potpourri aus der Operette: / Frau Luna (perhaps the author } \\
\text { of the arrangement is the composer himself), pub. Apollo- } \\
\text { Verlag, Berlin [PMO-II-4-583/75] } \\
\text { Die Meistersinger von Berlin / Grosses gesangs-Potpourri, } \\
\text { pub. Apollo-Verlag, Berlin [PMO-II-4-583/52] } \\
\text { Siamesiche Wachtparade Charakterstück, pub. Apollo- } \\
\text { Verlag, Berlin [PMO-II-4-187: D and KRG] } \\
\text { Berliner Luft / Marsch [PMO-II-4-630/4: T] } \\
\text { Ouvertüre / zur der Operette: / Im Reiche des Indra [PMO- } \\
\text { II-4-583/76: T] } \\
\text { Folies-Bergere [PMO-II-4-387: ZW] }\end{array}$ \\
\hline $\begin{array}{l}\text { Franz Lehár } \\
\text { (1870-1948) }\end{array}$ & $\begin{array}{l}\text { Immer nur lächeln / Lied aus der romantischen Operette } \\
\text { Das Land des Lächelns, pub. Glocken-Verlag, Wien [PMO- } \\
\text { II-4-584] } \\
\text { Großes Potpourri / aus / Zigeunerliebe / Operette in } 3 \text { Akten, } \\
\text { arr. Hans Schott, pub. Glocken-Verlag, Wien [PMO-II-4-622] } \\
\text { Schön ist die Welt / Lied aus der Operette, pub. Glocken- } \\
\text { Verlag, Wien [PMO-II-4-630/4] } \\
\text { Liebste glaub`an mich! / Lied aus der Operette Schön ist } \\
\text { die Welt, arr. Viktor Hruby, pub. W. Karczag, Leipzig [PMO- } \\
\text { II-4-630/14] } \\
\text { Grosses Potpourri aus der Operette Schön ist die Welt, } \\
\text { arr. Viktor Hruby, pub. W. Karczag, Leipzig [PMO-II-4-583/56] }\end{array}$ \\
\hline
\end{tabular}




\begin{tabular}{|c|c|}
\hline & $\begin{array}{l}\text { Mädel klein, Mädel fein! / Lied aus der Operette Der Graf } \\
\text { von Luxemburg, pub. Glocken-Verlag, Wien [PMO-II-4-589] } \\
\text { Melodienfolge / aus der Operette Der Graf von Lusemburg, } \\
\text { pub. Glocken-Verlag, Wien [PMO-II-4-616] } \\
\text { Großes Potpourri / nach Motiven der Operette Der } \\
\text { Rastelbinder, arr. Gust. Mahr, pub. Verlag von Josef } \\
\text { Weinberger, Leipzig-Wien [PMO-II-4-630/7] } \\
\text { Grosses Potpourri aus dem Sinspiel: Friederike, arr. Max } \\
\text { Rohlee, pub. Crescendo Theaterverlag, Berlin [PMO- } \\
\text { II-4-583/49] } \\
\text { Du bist meine Sonne / Lied aus der musikalischen Komödie } \\
\text { Giuditta, arr. Viktor Hruby, pub. W. Karczag, Leipzig [PMO- } \\
\text { II-4-620] } \\
\text { Ouvertüre / zur der Operette Wiener Frauen, pub. Glocken- } \\
\text { Verlag, Wien [PMO-II-4-181/1-12] } \\
\text { Jede Nacht träume ich... / Lied und Langsamer Walzer, pub. } \\
\text { Glocken-Verlag, Wien [PMO-II-4-607] } \\
\text { Ungarischer Marsch [PMO-II-4-583/52: ZW] }\end{array}$ \\
\hline $\begin{array}{l}\text { Ernst Urbach } \\
(1872-1927)\end{array}$ & $\begin{array}{l}\text { Apollo - Marsch, arr. Andreas Schorer, pub. Otto Wrede - } \\
\text { Regina Verlag, Berlin [PMO-II-4-463] }\end{array}$ \\
\hline $\begin{array}{l}\text { Paul Graener } \\
(1872-1944)\end{array}$ & $\begin{array}{l}\text { Sérénade pittoresque, pub. Richard Birnbach, Berlin [PMO- } \\
\text { II-4-583/33] }\end{array}$ \\
\hline $\begin{array}{l}\text { Samuel } \\
\text { Coleridge-Taylor } \\
(1875-1912)\end{array}$ & $\begin{array}{l}\text { Afrikanische Suite I / Negro Suite Op. 105, arr. L. Artok, pub. } \\
\text { B. Schotts Söhne, Mainz-Leipzig [PMO-II-4-583/8] } \\
\text { Afrikanische Suite II / Negro Suite Op. 105, arr. L. Artok, pub. } \\
\text { B. Schotts Söhne, Mainz-Leipzig [PMO-II-4-583/9] } \\
\text { Zigeuner Suite / Gipsy Suite Op. 104, arr. L. Artok, pub. B. } \\
\text { Schotts Söhne, Mainz-Leipzig [PMO-II-4-583/12] }\end{array}$ \\
\hline $\begin{array}{l}\text { Rudolf Kronegger } \\
(1875-1929)\end{array}$ & $\begin{array}{l}\text { Beim Heurigen / Potpourri, arr. F. Muuss, J.K. Richter, pub. } \\
\text { Bosworth and Co., Leipzig [PMO-II-4-583/15] }\end{array}$ \\
\hline $\begin{array}{l}\text { Fedele Rivelli } \\
(1875-1930)\end{array}$ & $\begin{array}{l}\text { Serenata napolitana / Neapolitanisches Ständchen, arr. } \\
\text { Ernst Urbach, pub. Otto Wrede, Berlin [PMO-II-4-621] }\end{array}$ \\
\hline $\begin{array}{l}\text { Giuseppe Becce } \\
(1877-1973)\end{array}$ & $\begin{array}{l}\text { Serenata della Laguna Op. 32, pub. Robert Lineau, Berlin } \\
\text { [PMO-II-4-630/23] }\end{array}$ \\
\hline $\begin{array}{l}\text { Hans Ailbout } \\
(1879-1957)\end{array}$ & $\begin{array}{l}\text { Humoreske in C-dur, pub. Rud. Erdmann u. Co., Leipzig } \\
\text { [PMO-II-4-583/23] } \\
\text { Magdalena / Reminiscenz, pub. Musikverlag Matth. Hohner } \\
\text { A.G., Berlin [PMO-II-4-583/32] } \\
\text { Rhapsodie Catalan, pub. Kawi-Verlag, Berlin \&W. Ehrler and } \\
\text { Co., Leipzig [PMO-II-4-583/16] }\end{array}$ \\
\hline
\end{tabular}




\begin{tabular}{|c|c|}
\hline $\begin{array}{l}\text { Jacob Gade } \\
(1879-1963)\end{array}$ & $\begin{array}{l}\text { Jalousie / Tango Tzigane, arr. Georges Martine, pub. Edition } \\
\text { Charles Brüll, Paris [PMO-II-4-389] }\end{array}$ \\
\hline $\begin{array}{l}\text { Wilhelm August } \\
\text { Lautenschläger [José } \\
\text { Armándola] } \\
(1880-1949)\end{array}$ & $\begin{array}{l}\text { Im Rosenhag / Pizzicato-Ständchen, arr. J. Armándola, pub. } \\
\text { Richard Birnbach, Berlin [PMO-II-4-630/17] } \\
\text { Gaukler im Dorf / Charakterstück, arr. J. Armándola, pub. } \\
\text { Richard Birnbach, Berlin [PMO-II-4-583/27, PMO-II-4-630/8] }\end{array}$ \\
\hline $\begin{array}{l}\text { Georg Freundorfer } \\
(1881-1940)\end{array}$ & $\begin{array}{l}\text { Lustiges Tirol Polka, arr. Johann Voehrs, pub. Rud. Erdman \& } \\
\text { Co., Leipzig [PMO-II-4-420: D and RKG] }\end{array}$ \\
\hline $\begin{array}{l}\text { Wilhelm Lindemann } \\
(1882-1941)\end{array}$ & Wenn die Soldaten, Marsch [PMO-II-4-388: ZW] \\
\hline $\begin{array}{l}\text { Karl Julius Sommer } \\
(1883-1962)\end{array}$ & $\begin{array}{l}\text { Suite in } 5 \text { Sätzen / Im sonningen Süden [PMO-II-4-583/63: } \\
\text { ZW] }\end{array}$ \\
\hline $\begin{array}{l}\text { Erich Otto [Erich } \\
\text { Otto Deutsch?, } \\
\text { musicologist } \\
(1883-1967)]\end{array}$ & $\begin{array}{l}\text { Koketterie / Kleine Serenade / Violinsolo mit } \\
\text { Orchesterbegleitung, arr. Walter Meissner [PMO-II-4-583/39] }\end{array}$ \\
\hline $\begin{array}{l}\text { Hans Gansser } \\
(1884-1959)\end{array}$ & $\begin{array}{l}\text { Kamerad, die Schicksalsstunde schlägt, text: Kurt Eggers. } \\
\text { Sheet music of the march song Waffen SS, consisting of } 1 \\
\text { card with music notation in } 6 \text { staffs and } 4 \text { stanzas of a song } \\
\text { below. [PMO-II-4-462] }\end{array}$ \\
\hline $\begin{array}{l}\text { Heinrich Steinbeck } \\
(1884-1967)\end{array}$ & $\begin{array}{l}\text { In alter Frische Marsch [PMO-II-4-395: ZW] } \\
\text { Regimentsgruss Marsch [PMO-II-4-395: ZW] }\end{array}$ \\
\hline $\begin{array}{l}\text { Eduard Künnecke } \\
(1885-1953)\end{array}$ & $\begin{array}{l}\text { Blaue Jungs fahren zur See, arr. Franz Stolzenwald, pub. D. } \\
\text { Räder, Leipzig [PMO-II-4-351: D and KRG] } \\
\text { Die Ordensritter-Ouvertüre, pub. Robert Rühle, Berlin } \\
\text { [PMO-II-4-583/21] } \\
\text { Grosse Melodienreihe / aus der Operette / Der Tenor der } \\
\text { Herzogin [PMO-II-4-583/67] } \\
\text { Romantische Ouvertüre pub. Richard Birnbach, Berlin } \\
\text { [PMO-II-4-583/18 (Cat. No. PMO-II-4-608: T)] }\end{array}$ \\
\hline $\begin{array}{l}\text { Karl Föderl } \\
(1885-1953)\end{array}$ & $\begin{array}{l}\text { Einmal in der Wochen fall' ich um / Wiener Lied [PMO- } \\
\text { II-4-630/8: T] }\end{array}$ \\
\hline $\begin{array}{l}\text { Gaetano Lama } \\
(1886-1950)\end{array}$ & $\begin{array}{l}\text { Tanz, mein blondes Mädel....! / (Cara piccina!) / } \\
\text { Neapolitanisches Lied, arr. Leopold Weninger, pub. D. Räder } \\
\text { Verlag, Leipzig [PMO-II-4-587] }\end{array}$ \\
\hline $\begin{array}{l}\text { Otto Witteborn } \\
(1886-1973)\end{array}$ & $\begin{array}{l}\text { Ein Fest im Gnomerich / Ballett-Suite Op. 28, pub. Ed. Bobe } \\
\text { and G. Bock, Berlin [PMO-II-4-583/3] }\end{array}$ \\
\hline
\end{tabular}




\begin{tabular}{|c|c|}
\hline $\begin{array}{l}\text { Herms Niel } \\
(1888-1954)\end{array}$ & $\begin{array}{l}\text { Matrosenlied / Marschlied [PMO-II-4-630/12: T] } \\
\text { Wir sind Kameraden / Marschlied [PMO-II-4-630/10: T] }\end{array}$ \\
\hline $\begin{array}{l}\text { Hermann Krome } \\
(1888-1955)\end{array}$ & $\begin{array}{l}\text { Die Mühle im Neckartal / Idyll, pub. Richard Birnbach, Berlin } \\
\text { [PMO-II-4-583/47] } \\
\text { Frühlig in der Heimat / Walzer, pub. Richard Birnbach, Berlin } \\
\text { [PMO-II-4-583/48] } \\
\text { Heidelberger Zecher / Walzer, pub. Richard Birnbach, Berlin } \\
\text { [PMO-II-4-583/46] }\end{array}$ \\
\hline $\begin{array}{l}\text { Ludwig Siede } \\
(1888-1956)\end{array}$ & $\begin{array}{l}\text { Vielliebchen / Intermezzo grazioso. / Op. 80, pub. Anton J. } \\
\text { Benjamin, Leipzig [PMO-II-4-615] } \\
\text { Chinesische Strassenserenade, pub. Karl Stemmler Verlag, } \\
\text { Leipzig [PMO-II-4-358] } \\
\text { Die Puppenparade / Charakterstück / Op. 146, pub. Karl } \\
\text { Stemmler Verlag, Leipzig [PMO-II-4-630/9 (Cat. No. PMO- } \\
\text { II-4-630/13: T)] } \\
\text { Herbstgedanken / Walzer-Intermezzo. / Op. 148, pub. Anton } \\
\text { J. Benjamin, Hamburg [PMO-II-4-608] }\end{array}$ \\
\hline $\begin{array}{l}\text { Carl Robrecht } \\
(1888-1961)\end{array}$ & $\begin{array}{l}\text { Niagara / Piano-Novelty, pub. Bosworth and Co., Bruxelles } \\
{[\text { PMO-II-4-583/68] }}\end{array}$ \\
\hline $\begin{array}{l}\text { Hans Ludwig Kormann } \\
\text { (1889-?) }\end{array}$ & $\begin{array}{l}\text { Groteske, pub. Maximilian Müller Musikverlag, Berlin [PMO- } \\
\text { II-4-583/55] }\end{array}$ \\
\hline $\begin{array}{l}\text { Willi Engel-Berger } \\
(1890-1946)\end{array}$ & $\begin{array}{l}\text { Mein Wellensittich Foxtrot Gesangs-Terzett, arr. Adolf } \\
\text { Steimel, pub. Monopol Liederverlag GmbH., Berlin [PMO- } \\
\text { II-4-371: D and KRG] }\end{array}$ \\
\hline $\begin{array}{l}\text { Edmund Nick } \\
(1891-1974)\end{array}$ & $\begin{array}{l}\text { Liebeswalzer aus dem Cine-Allianz-Film „Sechs Tage } \\
\text { Heimaturlaub”, arr. Franz Stolzenwald, pub. Musikverlag } \\
\text { Hans Sikorski, Leipzig [PMO-II-4-583/62] } \\
\text { Wir sind zwei gute Kameraden / Marschlied [PMO- } \\
\text { II-4-630/17:T] }\end{array}$ \\
\hline $\begin{array}{l}\text { Hanns Löhr } \\
(1892-1982)\end{array}$ & $\begin{array}{l}\text { Zauber der Wachau / Grosser Walzer, pub. Verlag von Julius } \\
\text { Bauer, Braunschweig [PMO-II-4-583/26] } \\
\text { Walc / W pięknej dolinie Isary [PMO-II-4-583/76: T] }\end{array}$ \\
\hline $\begin{array}{l}\text { Heinrich Strecker } \\
(1893-1981)\end{array}$ & $\begin{array}{l}\text { Äennchen von Tharau / Grosses Potpourri aus der Sinspiel- } \\
\text { Operette, pub. Wiener Boheme GmbH., Berlin [PMO- } \\
\text { II-4-583/65 (Cat. No. PMO-II-4-583/65: T)] } \\
\text { Sing mir das Lied noch Einmal / Langsam Walzer, arr. Oskar } \\
\text { Wagner, pub. Musikverlag Adolf Robitschek, Leipzig [PMO- } \\
\text { II-4-393: D and KRG] }\end{array}$ \\
\hline $\begin{array}{l}\text { Viktor Hruby } \\
(1894-1978)\end{array}$ & $\begin{array}{l}\text { Ein Jahrmarkt im Dorie, pub. Edition Scala, Wien-Berlin } \\
\text {-Leipzig [PMO-II-4-583/59] }\end{array}$ \\
\hline
\end{tabular}




\begin{tabular}{|c|c|}
\hline $\begin{array}{l}\text { Willy Schmidt-Gentner } \\
\text { (1894-1964) }\end{array}$ & $\begin{array}{l}\text { Ich bin heute ja so verliebt / Lied und langsamer / aus dem } \\
\text { Willy Forst-Film der Wien-Film „Operette”, pub. Cineton } \\
\text { Verlag GmbH., Berlin [PMO-II-4-395] }\end{array}$ \\
\hline $\begin{array}{l}\text { Nico Dostal } \\
(1895-1981)\end{array}$ & $\begin{array}{l}\text { Ein Besuch / Ein Folge seiner beliebsten Melodien, arr. } \\
\text { Richard Etlinger, pub. Dreima, Wiesbaden [PMO-II-4-614] }\end{array}$ \\
\hline $\begin{array}{l}\text { Robert Küssel } \\
(1895-1970)\end{array}$ & $\begin{array}{l}\text { Frühlingsträume, pub. Verlag Goldregen, Berlin [PMO- } \\
\text { II-4-612] }\end{array}$ \\
\hline $\begin{array}{l}\text { Jakob Christ } \\
(1895-1974)\end{array}$ & $\begin{array}{l}\text { Mit Sing - Sang und Kling - Klang Ein neues Soldatenlied, } \\
\text { arr. Bruno Hartmann, pub. Rud. Erdmann Co., Leipzig [PMO- } \\
\text { II-4-352 D and KRG] }\end{array}$ \\
\hline $\begin{array}{l}\text { Wilhelm Ernst Gabriel } \\
\text { [pseud. Wiga] } \\
\text { (1897-1964) }\end{array}$ & $\begin{array}{l}\text { Ein Lied für dich allein, Lied und langsam Walzer, arr. Horst } \\
\text { Kundritzki, pub. Edition Gabriel, Wilhelm Gabriel Verlag } \\
\text { für moderne Tanz und Unterhaltungmusik, Berlin [PMO- } \\
\text { II-4-385] }\end{array}$ \\
\hline $\begin{array}{l}\text { Will Meisel } \\
(1897-1967)\end{array}$ & $\begin{array}{l}\text { Die Frau im Spiegel Grosses Potpourri aus der } \\
\text { gleichnamigen Lustspiel-Operette, arr. Franz Stolzenwald } \\
\text { [PMO-II-4-583/53] }\end{array}$ \\
\hline $\begin{array}{l}\text { Bruno Bartsch } \\
(1898-1980)\end{array}$ & $\begin{array}{l}\text { Flitterwochen / Intermezzo, arr. Adolf Steimel, pub. Erich } \\
\text { Paftänier, Leipzig [PMO-II-4-583/42 (Cat. No. PMO-II-4-595: } \\
\text { KRG)] }\end{array}$ \\
\hline $\begin{array}{l}\text { Reiny Roland } \\
(1898-1991)\end{array}$ & $\begin{array}{l}\text { Zum } 5 \text { Uhr Tee, Melodienfolge aus beliebten Tonfilm } \\
\text { und Tanzschlagern. Ausgabe für Salon-Orchester } \\
\text { Saxofonstimmen, pub. Dr Hans Sikorski, Leipzig [PMO- } \\
\text { II-4-190/1-15 } 9 \text { (Cat. No. PMO-II-4-192: KRG)] }\end{array}$ \\
\hline $\begin{array}{l}\text { Giulio de Micheli } \\
(1899-1940)\end{array}$ & $\begin{array}{l}\text { Küsse im Dunkeln / Serenata Op. 33, pub. Anthon J. } \\
\text { Benjamin, Leipzig [PMO-II-4-630/13] } \\
\text { Herbstlied Op. 64, arr. Leopold Weninger, pub. D. Räder } \\
\text { Verlag, Leipzig [PMO-II-4-583/31] } \\
\text { Suite di Danze / a) Orientalischer Tanz b) Spanischer } \\
\text { Tanz c) Burlesker Tanz Op. 123, pub. Erich Plessow and Co. } \\
\text { Kommanditgeselschaft, Berlin [PMO-II-4-583/10] }\end{array}$ \\
\hline $\begin{array}{l}\text { Pierre Blaauw } \\
(1899-1943)\end{array}$ & $\begin{array}{l}\text { Die spieluhr / Glocken-Intermezzo, arr. E. Heansch, pub. } \\
\text { Bosworth \& Co., Köln-Wien [PMO-II-4-606 (Cat. No. PMO- } \\
\text { II-4-606: T)] }\end{array}$ \\
\hline $\begin{array}{l}\text { Erich Plessow } \\
(1899-1977)\end{array}$ & $\begin{array}{l}\text { Ich suche eine Freundin für die Ferien / Foxtrot, arr. } \\
\text { Franz Stolzenwald, pub. Edition Standars, Musik und } \\
\text { Bühnenverlag, Erich Plessow \& Co., Berlin [PMO-II-4-394] }\end{array}$ \\
\hline
\end{tabular}




\begin{tabular}{|c|c|}
\hline $\begin{array}{l}\text { Fred Raymond } \\
(1900-1954)\end{array}$ & $\begin{array}{l}\text { Komm trink und lach am Rhein / Walzer-lied [PMO- } \\
\text { II-4-630/9: T] } \\
\text { Für mich gibts nur eine Frau... / Foxtrot [PMO-II-4-365: } \\
\text { KRG] }\end{array}$ \\
\hline $\begin{array}{l}\text { Heinz Munkel } \\
(1900-1961)\end{array}$ & $\begin{array}{l}\text { Das Hohnsteiner Kasperle / Charakterstück, arr. Bernh. Egg, } \\
\text { pub. N. Simrock, Leipzig [PMO-II-4-603] }\end{array}$ \\
\hline $\begin{array}{l}\text { Willy Richartz } \\
(1900-1972)\end{array}$ & $\begin{array}{l}\text { Traum - Melodien / Walzer, arr. L. Kletsch, pub. Paul Paasch } \\
\text { „Florida“ Musikverlag, Berlin [PMO-II-4-583/37] } \\
\text { Bayerische G'schichten / Walzer, pub. Musikverlag „Florida”, } \\
\text { Berlin. [PMO-II-4-630/10 (Cat. No. PMO-II-4-603: T)] }\end{array}$ \\
\hline $\begin{array}{l}\text { Ernst Fischer } \\
(1900-1975)\end{array}$ & $\begin{array}{l}\text { Bummel am Abend Intermezzo, pub. Heinrichshofen's } \\
\text { Verlag, Magdeburg [PMO-II-4-583/5] }\end{array}$ \\
\hline $\begin{array}{l}\text { Walther Noack } \\
(1900-1992)\end{array}$ & $\begin{array}{l}\text { Einzung des Schneekönigs / Charakterstück Op. 17, pub. } \\
\text { W. Huhn, Musikalien-Verlag, Lüdenscheid [PMO-II-4-630/2, } \\
\text { PMO-II-4-583/35] }\end{array}$ \\
\hline $\begin{array}{l}\text { Werner Bochmann } \\
(1900-1993)\end{array}$ & $\begin{array}{l}\text { In einem weissen Mahnfeld / Langsamer Walzer, arr. } \\
\text { Friedrich Schröder [PMO-II-4-356: D and KRG] }\end{array}$ \\
\hline $\begin{array}{l}\text { Billy Bartholomew } \\
(1901-1972)\end{array}$ & Jeden Abend Foxtrot [PMO-II-4-362: KRG]. \\
\hline $\begin{array}{l}\text { Walter Jäger } \\
(1901-1975)\end{array}$ & $\begin{array}{l}\text { Kleine Parade / Intermezzo, arr. Schönian, pub. Taunus- } \\
\text { Verlag, Frankfurt a. M. [PMO-II-4-583/64] } \\
\text { Wenn kleine Mädchen von der Liebe träumen Melodie } \\
\text { Foxtrot, arr. Helmut Gardens, pub. Taunus Verlag H.L. Grahl, } \\
\text { Frankfurt a. M. [PMO-II-4-368] } \\
\text { Du sollst um mich nicht weinen / Langs. Walzer [PMO- } \\
\text { II-4-583/52: T] }\end{array}$ \\
\hline $\begin{array}{l}\text { Josef M. Kratky } \\
(1901-1975)\end{array}$ & $\begin{array}{l}\text { Hinter der Letzten Laterne... Lied und langsamer, arr. Josef } \\
\text { Kurz, pub. Hans Kratky Musikverlag, Wien-Leipzig [PMO- } \\
\text { II-4-390] }\end{array}$ \\
\hline $\begin{array}{l}\text { Gerhard Mohr } \\
(1901-1979)\end{array}$ & $\begin{array}{l}\text { Regenbogen-Walzer / Konzertwalzer, pub. D. Räder, Leipzig } \\
\text { [PMO-II-4-604] } \\
\text { Stunden - die man nie vergessen kann / Lied und } \\
\text { langsamer Walzer, pub. Dreikland Verlag A.G., Berlin [PMO- } \\
\text { II-4-384] } \\
\text { Du hast den schönsten Mund / Monika-Luise! Tango, pub. } \\
\text { Musikverlag Peter Schaeffers, Berlin [PMO-II-4-372: D and } \\
\text { KRG] }\end{array}$ \\
\hline $\begin{array}{l}\text { Zdeněk Hůla [pseud. } \\
\text { Zdenko Bayer] } \\
\text { (1901-1986) }\end{array}$ & $\begin{array}{l}\text { Vojáček / charakteristická skladba / Der kleine soldat / } \\
\text { Charakterstück, arr. B. Leopold, pub. Edition Continental, } \\
\text { Praha [PMO-II-4-610] }\end{array}$ \\
\hline
\end{tabular}




\begin{tabular}{|c|c|}
\hline $\begin{array}{l}\text { Jupp Schmitz } \\
(1901-1991)\end{array}$ & $\begin{array}{l}\text { Denn ich bin ein rheinisher Junge Foxtrot, arr. Adolf Steimel, } \\
\text { pub. Jupp Schmitz Verlag, Köln [PMO-II-4-378] }\end{array}$ \\
\hline $\begin{array}{l}\text { Frank Fux [Fox] } \\
(1902-1965)\end{array}$ & $\begin{array}{l}\text { Weisst du noch / Tango Serenade aus dem Algefa-Film - } \\
\text { „Aufruhr im Damenstift”, arr. Gerhard Mohr, pub. Musikverlag } \\
\text { Peter Schaeffers, Berlin [PMO-II-4-392] }\end{array}$ \\
\hline $\begin{array}{l}\text { Eldo di Lazzaro } \\
(1902-1968)\end{array}$ & $\begin{array}{l}\text { Am Abend auf der Heide Foxtrot, arr. Franz Stolzenwald, } \\
\text { pub. Edizioni Musicali „Emi” Milano, Galleria del Corso [PMO- } \\
\text { II-4-382: } \text { D and KRG] }\end{array}$ \\
\hline $\begin{array}{l}\text { Josef Rixner } \\
(1902-1973)\end{array}$ & $\begin{array}{l}\text { Der arme Jonathan / Potpourri aus der Operette, arr. } \\
\text { Millöker-Rixner, pub. Bühnen und Musikalienverlag, Josef } \\
\text { Weinberger, Berlin [PMO-II-4-583/50] } \\
\text { Bagatelle-Ouverture No. } 27 \text { [PMO-II-4-182] } \\
\text { Tanz der Maske / Serenade und Capriccio, pub. Kawi-Verlag } \\
\text { Karl Wilke, Berlin-Wilmersdorf [PMO-II-4-583/25 (Cat. No. } \\
\text { PMO-II-4-594: KRG)] } \\
\text { Spiel im Wind, pub. Musikverlag Matth. Hohner A.G., Berlin } \\
\text { [PMO-II-4-583/34] } \\
\text { Morgen im Mai [PMO-II-4-583/34: ZW] } \\
\text { Spitzbub [PMO-II-4-630/16: T] }\end{array}$ \\
\hline $\begin{array}{l}\text { Fritz Domina } \\
(1902-1975)\end{array}$ & $\begin{array}{l}\text { Lustiger Matrosen-tanz, pub. Harth Verlag, Erich Pastänier, } \\
\text { Leipzig [PMO-II-4-359] }\end{array}$ \\
\hline $\begin{array}{l}\text { Heinrich Steiner } \\
(1903-1982)\end{array}$ & $\begin{array}{l}\text { Serenata appasionata, pub. „Florida” Musikverlag und } \\
\text { Sortiment, Paul Paasch, Berlin [PMO-II-4-583/13] }\end{array}$ \\
\hline $\begin{array}{l}\text { Ludwig Schmidseder } \\
\text { (1904-1971) }\end{array}$ & $\begin{array}{l}\text { Ich wollt' ich hätt' / im Wirtshaus gleich mein Bett! / } \\
\text { Wienerlied, arr. Franz Stolzenwald, pub. Musikverlag Peter } \\
\text { Schaeffers, Berlin [PMO-II-4-591] } \\
\text { Potpourri / Melodie der Nacht [PMO-II-4-604: ZW] }\end{array}$ \\
\hline $\begin{array}{l}\text { Walter Baumgartner } \\
\text { (1904-1997) }\end{array}$ & $\begin{array}{l}\text { Noch sind die Tage der Rosen / Lied, arr. Josef Németi, pub. } \\
\text { D. Räder, Leipzig [PMO-II-4-583/63] }\end{array}$ \\
\hline $\begin{array}{l}\text { Hans Otten } \\
(1905-1942)\end{array}$ & $\begin{array}{l}\text { Du kannst von mir alles haben / Schunkelwalzer [PMO- } \\
\text { II-4-583/70: T] }\end{array}$ \\
\hline $\begin{array}{l}\text { Mátyás György Seiber } \\
\text { [G.S. Mathis] } \\
(1905-1960)\end{array}$ & $\begin{array}{l}\text { Fesival at Sevilla / Spanish Rhapsody, pub. Schott - Co. Ltd., } \\
\text { London [PMO-II-4-583/7] }\end{array}$ \\
\hline $\begin{array}{l}\text { Michael Jary } \\
(1906-1988)\end{array}$ & $\begin{array}{l}\text { Roter Mohn Tango aus dem Algefa-Film der Terra Filmkunst } \\
\text { /“Schwarzfahrt ins Glück", pub. Wiener Boheme Verlag } \\
\text { GmbH., Berlin-Wien [PMO-II-4-366] }\end{array}$ \\
\hline
\end{tabular}




\begin{tabular}{|c|c|}
\hline $\begin{array}{l}\text { Gerhard Winkler } \\
(1906-1977)\end{array}$ & $\begin{array}{l}\text { Unter blühenden Orangen / Ständchen, pub. Apollo Verlag, } \\
\text { Berlin [PMO-II-4-630/11] } \\
\text { Japanisches Teehaus / Intermezzo, pub. Musikverlag Paul } \\
\text { Schmidt, Berlin [PMO-II-4-590] } \\
\text { Im Herbst / Suite in } 3 \text { Sätzen / 1. Fallende Blätter / 2. } \\
\text { Herbstlied / 3. Parforce-Jagd [PMO-II-4-583/72] } \\
\text { Der kleine Postillon / Tanz - Intrmezzo, arr. Helmut Gardens, } \\
\text { pub. Edition Wilhelm Gabriel Verlag, Berlin [PMO-II-4-396: D } \\
\text { and KRG] } \\
\text { Klein Sennerin / Lied und Tango, pub. Edition } \\
\text { Gabriel, Wilhelm Gabriel Verlag für moderne Tanz und } \\
\text { Unterhaltungmusik, Berlin [PMO-II-4-380: D and KRG] } \\
\text { Georgine / Foxtrot [PMO-II-4-610: T] }\end{array}$ \\
\hline $\begin{array}{l}\text { Michael Jary } \\
\text { [Maksymilian Michał } \\
\text { Jarczyk] } \\
\text { (1906-1988) }\end{array}$ & Der Onkel Jonathan / Foxtrot [PMO-II-4-583/59: T] \\
\hline $\begin{array}{l}\text { Erich Börschel } \\
(1907-1988)\end{array}$ & Tanz der Geishas / Foxtrot-Intermezzo [PMO-II-4-583/72: T] \\
\hline $\begin{array}{l}\text { Gino Redi [P.G. Redi] } \\
(1908-1962)\end{array}$ & $\begin{array}{l}\text { Die Phantastische Nacht / Tango Bolero, pub. Redi S.A. } \\
\text { Edizioni Musicali Milano, Galleria dei Corso [PMO-II-4-363: D } \\
\text { and KRG] }\end{array}$ \\
\hline $\begin{array}{l}\text { Franz Grothe } \\
\text { (1908-1982) }\end{array}$ & $\begin{array}{l}\text { Lied der Nachtigall / aus dem Film der Terra Filmkunst } \\
\text { GmbH. / „Die schwedische Nachtigall", arr. Walter Borchert, } \\
\text { pub. Wiener Boheme Verlag, GmbH., Berlin [PMO-II-4-583/79 } \\
\text { (Cat. No. PMO-II-4-583/79: T)] } \\
\text { Postillion Lied [PMO-II-4-583/79: T] } \\
\text { Grüss mir die Berolina-Berliner Lied [PMO-II-4-604:T] } \\
\text { Wenn unser Berlin ver dunkelt ist-Marschfoxtrot [PMO- } \\
\text { II-4-604: T] }\end{array}$ \\
\hline $\begin{array}{l}\text { Alberto Semprini } \\
(1908-1990)\end{array}$ & $\begin{array}{l}\text { Leila Rhythmischer Foxtrot [PMO-II-4-376: D and KRG (Cat. } \\
\text { No. PMO-II-4-608: T)] }\end{array}$ \\
\hline $\begin{array}{l}\text { Herbert Küster } \\
(1909-1986)\end{array}$ & $\begin{array}{l}\text { Teerose / Lyrisches Intermezzo, arr. Hartwig von Platen, pub. } \\
\text { Richard Birnbach, Berlin [PMO-II-4-630/15] }\end{array}$ \\
\hline $\begin{array}{l}\text { Edmund Kötscher } \\
\text { (1909-1990) }\end{array}$ & $\begin{array}{l}\text { Wilde Rosen / Walzer, arr. Horst Kudritzki, pub. Richard } \\
\text { Birnbach, Berlin [PMO-II-4-583/41] } \\
\text { Wenn die Lichter wieder scheinen / Foxtrot [PMO- } \\
\text { II-4-583/67: T] } \\
\text { Dorfmusikanten [PMO-II-4-396: ZW] }\end{array}$ \\
\hline
\end{tabular}




\begin{tabular}{|c|c|}
\hline $\begin{array}{l}\text { Hans Busch } \\
(1909-1996)\end{array}$ & $\begin{array}{l}\text { Dideldideldum, Dideldideldei / Foxtrot, arr. Horst Kudritzki, } \\
\text { pub. Edition Gabriel, Berlin [PMO-II-4-375: D and KRG] }\end{array}$ \\
\hline $\begin{array}{l}\text { Friedrich Schröder } \\
(1910-1972)\end{array}$ & $\begin{array}{l}\text { Ja, so war es zu Grossmutters Zeiten / Lied und Tango, pub. } \\
\text { Alfred Klabunde Musikverlag, Berlin [PMO-II-4-381] } \\
\text { Ein Glück, dass man sich so verlieben kann! / Lied und } \\
\text { foxtrot, pub. Musikverlag Peter Schaeffers, Berlin. On } \\
\text { the catalogue card, it is written that it is te aria from the } \\
\text { operetta Hochzeitsnacht im Paradis by Heinz Hautschke. } \\
\text { [PMO-II-4-353: D oraz KRG (Cat. No. PMO-II-4-583/64: T)] }\end{array}$ \\
\hline $\begin{array}{l}\text { Nino Casiroli } \\
(1910-1975)\end{array}$ & $\begin{array}{l}\text { Nie war Musik so schön / Melodie Foxtrot [PMO-II-4-364: D } \\
\text { and KRG (Cat. No. PMO-II-4-583/68: T)] }\end{array}$ \\
\hline $\begin{array}{l}\text { Horst Kudritzki } \\
(1911-1970)\end{array}$ & $\begin{array}{l}\text { Von } 8 \text { bis um 8! Melodie Foxstrot, pub. Monopol-Lieder } \\
\text { Verlag GmbH. [PMO-II-4-361: D and KRG] }\end{array}$ \\
\hline $\begin{array}{l}\text { Ralph Maria Siegel } \\
(1911-1972)\end{array}$ & $\begin{array}{l}\text { In Freundschaft / Tango und Konzertlied, arr. Franz } \\
\text { Stolzenwald, pub. Musikverlag Peter Schaeffers, Berlin [PMO- } \\
\text { II-4-391: D and KRG] } \\
\text { Briefe, die dich nie erreichten... Lied und Melodie-Foxtrot, } \\
\text { arr. Adolf Steimel, pub. Albert Bennefeld Musikverlag, Berlin } \\
\text { [PMO-II-4-369] } \\
\text { Sing ein Lied - wenn du mal traurig bist Foxtrot, pub. Albert } \\
\text { Bennefeld Musikverlag, Berlin [PMO-II-4-370] } \\
\text { Unter ser roten Laterne von St. Pauli Tangolied, pub. } \\
\text { Musikverlag Peter Schaeffers, Berlin [PMO-II-4-372: D and } \\
\text { KRG] } \\
\text { Kleiner Hampelmann / Foxtrot-Intermezzo [PMO- } \\
\text { II-4-583/65: T] } \\
\text { Heut wird ein Märchen wahr / Tango [PMO-II-4-606: T] }\end{array}$ \\
\hline $\begin{array}{l}\text { Cosimo Di Ceglie } \\
(1913-1980)\end{array}$ & Oh Marie, oh Marie! / Foxtrot [PMO-II-4-583/62: T] \\
\hline $\begin{array}{l}\text { Lotar Olias } \\
(1913-1990)\end{array}$ & $\begin{array}{l}\text { Die nacht sieht mich so seltsam an mit ihrer Sternen / Lied } \\
\text { und langsamer Walzer, arr. Franz Stolzenwald, pub. Teo-Ton } \\
\text { Verlag, Berlin [PMO-II-4-387] } \\
\text { Foxtrot auf dem Puppenklavier / Foxtrott-Intermezzo, arr. } \\
\text { Walter Meissner, pub. Teo-Ton-Verlag, Berlin [PMO-II-4-598: } \\
\text { D and KRG] }\end{array}$ \\
\hline $\begin{array}{l}\text { Franz Josef Breuer } \\
\text { (1914-1996) }\end{array}$ & $\begin{array}{l}\text { Weit ist der Weg in die Heimat / Lied und Tango, arr. Franz } \\
\text { Stolzenwald, pub. W. Ehrler \& Co, Leipzig [PMO-II-4-374] }\end{array}$ \\
\hline
\end{tabular}




\begin{tabular}{|l|l|}
\hline $\begin{array}{l}\text { Børge Friis } \\
(1914-1998)\end{array}$ & Jedertanzt / Foxtrot [PMO-II-4-583/53: T] \\
\hline $\begin{array}{l}\text { Karl Bette } \\
(1916-2006)\end{array}$ & $\begin{array}{l}\text { Foxtrot Bitte, bitte, lieber Geiger ... mach Musik für mich!, } \\
\text { pub. Karl Bette (lack of place of publishing) [PMO-II-4-373] }\end{array}$ \\
\hline
\end{tabular}

\section{b) Compositions by authors difficult to identify (alphabetically)}

\begin{tabular}{|l|l|}
\hline Friedrich Wilhelm & $\begin{array}{l}\text { Geisterzug um Mitternacht / Charakterstück / Op. 48, } \\
\text { arr. J. Engleman, pub. Bosworth und Co., Bruxelles [PMO- } \\
\text { II-4-583/24] }\end{array}$ \\
\hline B. Leopold & $\begin{array}{l}\text { Plavovláska / Die blond Puppe / Intermezzo / Op. 49, pub. } \\
\text { Edition Continental, Praha [PMO-II-4-617] } \\
\text { Galanterie / Walzer Op. 93, pub. Edition Continental, Praha } \\
\text { [PMO-II-4-601] }\end{array}$ \\
\hline Charlotte Baerenz & $\begin{array}{l}\text { Bei Kerzenlicht [PMO-II-4-360: KRG (Cat. No. PMO- } \\
\text { II-4-583/63: T)] }\end{array}$ \\
\hline Willy Baldamus & $\begin{array}{l}\text { Triumph der Liebe Marsch [PMO-II-4-384: ZW] } \\
\text { Unter Fahnen und Standarten Marsch [PMO-II-4-384: ZW] }\end{array}$ \\
\hline Carl Barth & $\begin{array}{l}\text { Nordische Ballade / Konzertstück, pub. Musikverlag Math. } \\
\text { Hohner, Berlin-Wien [PMO-II-4-630/12] }\end{array}$ \\
\hline Bruno Bauer & $\begin{array}{l}\text { Wienerisch im 3/4 Takt / Walzer, pub. Musikverlag Adolf } \\
\text { Rabitschek, Wien-Leipzig-Berlin [PMO-II-4-630/6] }\end{array}$ \\
\hline Lüdwig Bernaüer & $\begin{array}{l}\text { Wenn es wo noch Märchen gibt... / Lied und langsamer } \\
\text { Walzer, arr. Josef Kurz, pub. Hans Kratky Musikverlag Wien- } \\
\text { Leipzig [PMO-II-4-390] }\end{array}$ \\
\hline Fred Caphat & $\begin{array}{l}\text { Wenn ich rote Rosen seh' / Lied, pub. Wiener Boheme Verlag } \\
\text { GmbH., Berlin [PMO-II-4-583/78], pub. C.F. Peters, Leipzig } \\
\text { [PMO-II-4-630/24] }\end{array}$ \\
\hline Walter Borchert & $\begin{array}{l}\text { Eccenctric Foxtrott / Novelty Piano-Solo with Orchestra, } \\
\text { pub. Suppan's Verlag, Dusseldorf [PMO-II-4-613] }\end{array}$ \\
\hline $\begin{array}{l}\text { Kleine Ironien / Caprice / Lied, pub. Paul Paasch „Florida” } \\
\text { Musikverlag, Berlin. [PMO-II-4-583/66, PMO-II-4-592] } \\
\text { In einem küheln Grunde / Lied, pub. Paul Paasch „Florida”, } \\
\text { Berlin [PMO-II-4-592] }\end{array}$ \\
\hline Hano
\end{tabular}




\begin{tabular}{|c|c|}
\hline Franz Doello & $\begin{array}{l}\text { Kleine Mitsu (Drüben in meiner Heimat) / Langsam Walzer, } \\
\text { arr. Franz Mück, pub. Echo Musikverlag GmbH., Berlin [PMO- } \\
\text { II-4-388: D and KRG] }\end{array}$ \\
\hline A. Escobar & La Principessa del Valzer [PMO-II-4-583/77] \\
\hline G. Fabiani & Venezia Marsch [PMO-II-4-607: ZW] \\
\hline Fritz German & $\begin{array}{l}\text { Ather Wellen! / (Onde Eteree) / Wiener Walzer No. 2, pub. } \\
\text { Isetem - Icilio Sterbini, Roma [PMO-II-4-630/16, PMO- } \\
\text { II-4-583/77 (Cat. No. PMO-II-4-600: T)] }\end{array}$ \\
\hline G. Groitzsch & $\begin{array}{l}\text { Der Jongleur / Excentric Novelette, pub. Bosworth u. Co., } \\
\text { Leipzig [PMO-II-4-583/44] }\end{array}$ \\
\hline B. Hauer & Wienerisch im 3/4 Takt / Walzer [PMO-II-4-630/6: T] \\
\hline Carl Hauschild & Frohsinn / Marsch [PMO-II-4-630/11: T] \\
\hline $\begin{array}{l}\text { Hans A. Heumann } \\
\text { [Richard Werner } \\
\text { Heymann (?)] }\end{array}$ & Rhapsodie Nr 1 [PMO-II-4-600: KRG] \\
\hline $\begin{array}{l}\text { L. Hildebrandt- } \\
\text { Leuschner }\end{array}$ & $\begin{array}{l}\text { Alt-Berlin / im Walzertakt / Walzer-Potpourri [PMO- } \\
\text { II-4-630/23: T] }\end{array}$ \\
\hline Josef Holetschek & $\begin{array}{l}\text { Fidele Bauern Polka, pub. P. Raasch, Musikverlag, Berlin } \\
\text { [PMO-II-4-354: D and KRG] }\end{array}$ \\
\hline Bobby Hönn & $\begin{array}{l}\text { Mein Glück / Langsamer Walzer, pub. Eden Musikverlag } \\
\text { Glauchau Inh. Robert Hönn (lack of place of publishing) } \\
\text { [PMO-II-4-386] }\end{array}$ \\
\hline $\begin{array}{l}\text { Michaił J. Ippolitow- } \\
\text { Iwanow }\end{array}$ & Suita / II część / Szkice kaukaskie [PMO-II-4-583/77: T] \\
\hline Wendelin Kopetzky & Egerländer / Marsch [PMO-II-4-630/3: T] \\
\hline F. Kowary & $\begin{array}{l}\text { Wie schön bist du / mein Heimatland / Lied [PMO- } \\
\text { II-4-630/7: T] }\end{array}$ \\
\hline R. Kronegger-Muss & Beim Heurigen / Potpourri [PMO-II-4-583/15: T] \\
\hline $\begin{array}{l}\text { (?) Krüger- } \\
\text { Hanschmann }\end{array}$ & Tausend Wochen / Foxtrot [PMO-II-4-583/54: T; ZW] \\
\hline Georg Lohmann & $\begin{array}{l}\text { Bayrische Polka / Solo für Pousaune, arr. Matthias Perl, pub. } \\
\text { Friedrich Wilhelm Fröhlich, Berlin [PMO-II-4-583/36] }\end{array}$ \\
\hline Erich Lutz & $\begin{array}{l}\text { Faschingsgeister / Walzer, arr. Karl Bucholz, pub. Paul Paasch } \\
\text { „Florida” Musikverlag Sortiment, Berlin [PMO-II-4-583/51] }\end{array}$ \\
\hline Carl May & $\begin{array}{l}\text { Ouvertüre über Eine Kreutzer Etüde Op. 36, pub. Albert } \\
\text { Schaper, Berlin [PMO-II-4-599] }\end{array}$ \\
\hline
\end{tabular}




\begin{tabular}{|c|c|}
\hline Ferry Muhr & $\begin{array}{l}\text { So war's in Wien / Konzertwalzer, pub. Albert Bennefeld, } \\
\text { Berlin [PMO-II-4-583/80] }\end{array}$ \\
\hline W. Nehl & $\begin{array}{l}\text { Zigeuner Ständchen Op. } 32 \text { / Serenade Tzigane / Morceau } \\
\text { characteristique, pub. Louis Oertel Musikverlag, Hannover } \\
\text { [PMO-II-4-583/2] }\end{array}$ \\
\hline Alfons Plank & $\begin{array}{l}\text { Der kleine Wildfang / Galopp, arr. Leopold Weninger, pub. D. } \\
\text { Räder, Leipzig [PMO-II-4-583/28, PMO-II-4-588] }\end{array}$ \\
\hline Wladimir Pogorelow & $\begin{array}{l}\text { Ständchen, arr. Bruno Kartmann, pub. Härth Verlag, Leipzig } \\
\text { [PMO-II-4-583/61] }\end{array}$ \\
\hline $\begin{array}{l}\text { Ferdinand Poliakin } \\
(18 . .-1921)\end{array}$ & $\begin{array}{l}\text { Imitation des petits Tambours F. Poliakin, pub. Bosworth u. } \\
\text { Co., Leipzig [PMO-II-4-583/29] }\end{array}$ \\
\hline Martin Schönicke & $\begin{array}{l}\text { Feldpost für Annchen / Lied, arr. Gerhard Mohr, pub. Arcadia } \\
\text { Verlag GmbH., Berlin [PMO-II-4-419] }\end{array}$ \\
\hline Otto Stolzenwald & $\begin{array}{l}\text { Der erste Schritt / Lustiges Intermezzo, pub. Dreiklang- } \\
\text { Dreimasken Bühen und Musikverlag, Berlin [PMO- } \\
\text { II-4-583/45] }\end{array}$ \\
\hline Rudolf Tichy & Osterreichische Wachtparade [PMO-II-4-393: ZW] \\
\hline Stassi D. Tombulis & $\begin{array}{l}\text { Traum von Haiti / Ein Südsee Tango, arr. Franz Stolzenwald, } \\
\text { pub. Harth-Verlag Erich Pastänier, Leipzig [PMO-II-4-350: D } \\
\text { and KRG (Cat. No. PMO-II-4-583/61: T)] }\end{array}$ \\
\hline $\begin{array}{l}\text { Joska Vidák } \\
\text { [Hungarian composer] }\end{array}$ & $\begin{array}{l}\text { Csibi / Ungarische Geigenpolka, arr. Bruno Hartmann, pub. } \\
\text { Aug. Cranz GmbH., Leipzig [PMO-II-4-619] }\end{array}$ \\
\hline
\end{tabular}

\section{c) Not identified compositions and works written after the war, sent to the Department of Collections of the Museum in Oświęcim}

\begin{tabular}{|l|l|}
\hline NN & $\begin{array}{l}\text { Die Schönste Zeit des Lebens (Moderato). The musical } \\
\text { material consists of } 28 \text { hand-written cards. On the cards with } \\
\text { numbers } 16 \text { and } 20 \text { there is number of inmate "5665"57, on } \\
\text { the cards } 22 \text { and } 24 \text { number "5131" (probably copied from } \\
\text { the print). [PMO-II-4-357] }\end{array}$ \\
\hline
\end{tabular}

57 In the card of a print, with cat. No. PMO-II-4-395, it is written that Antoni Gargul (number 5665) was working in the orchestra of the main camp as a Notenschreibert (scribe). It is also known that he was a drummer who was able to make the audience laugh. See: Ignacy Szczepański, Häftlingskapelle, Warszawa 1990, passim. 


\begin{tabular}{|c|c|}
\hline NN & $\begin{array}{l}\text { Ich wollt, ich hätt im Wirtshaus gleich mein Bett! The } \\
\text { musical material consists of } 15 \text { hand-written cards. All cards } \\
\text { with the seal of the chapel. [PMO-II-4-355] }\end{array}$ \\
\hline NN & $\begin{array}{l}\text { Lack of title. Musical material incomplete, one hand-written } \\
\text { card. On the top, on the frayed edge "...in Cuwar..." On the } \\
\text { reverse, a trace of the camp orchestra's seal. [PMO-II-4-193] }\end{array}$ \\
\hline NN & $\begin{array}{l}\text { Lack of title. Musical material incomplete. Only one card } \\
\text { preserved with notes, under them a text of a song in } \\
\text { German. In the right-upper corner, a number of page: "27", } \\
\text { in the left corner - "espressivo". In the right-below corner, } \\
\text { there is a description: "Musikaliendruckerei E. Leeb, Wien 20.." } \\
\text { [PMO-II-4-194] }\end{array}$ \\
\hline $\begin{array}{l}\text { Karpiński (? } \\
\text { Information on the } \\
\text { card) - Karol Kurpiński }\end{array}$ & $\begin{array}{l}\text { Uwertura / do Op. Leśnicy / z Krunickiej Puszczy / K. M. } \\
\text { / } 944 \text { r. / Auschwitz (?). Musical material of the overture } \\
\text { to the opera Leśnicy z Krunickiej Puszczy - incomplete. A } \\
\text { manuscript written in pencil on the staff paper. Pages with } \\
\text { numbers. A manuscript is kept in the cardboard folder with } \\
\text { number "158". Inside the folder, there are } 3 \text { cards: 1) a sketch } \\
\text { of the song Daremne żale, 2) unidentified sketch with the } \\
\text { signature "Kip"; 3) a sketch of a symphonic piece Moderato } \\
\text { ala Mazur for four-voice choir and symphonic orchestra. } \\
\text { The musical material consists of } 10 \text { cards. Perhaps it is an } \\
\text { attempt to reconstruct fragments of the opera Leśniczy z } \\
\text { Kozienieckiej Puszczy by Karol Kurpiński. In the accessible } \\
\text { musical literature, there is no such composer as Karpiński } \\
\text { or a composition titled Leśnica z Krunickiej Puszczy, so the } \\
\text { composition by Kurpiński seems probable. [PMO-II-4-306] }\end{array}$ \\
\hline $\begin{array}{l}\text { music: Edmund } \\
\text { Dehnert } \\
\text { music: Howard Poteet }\end{array}$ & $\begin{array}{l}\text { For the Dead Children of Auschwitz. Poem. A notebook } \\
\text { with notes and text of the piece. Male voice and piano. } \\
\text { It contains } 7 \text { hand-written cards, in cardboard, Brigid, } \\
\text { red covers. A description on the cover: "FOR THE DEAD } \\
\text { CHILDREN OF AUSCHWITZ / POEM BY G. HOWARD POTEET / } \\
\text { MUSIC BY EDMUND DEHNERT". Attached a paper written in } \\
\text { English, with signatures of the piece's authors. Performance } \\
\text { remarks on the first page. Post-war composition. [PMO- } \\
\text { II-4-345] }\end{array}$ \\
\hline
\end{tabular}




\begin{tabular}{|c|c|}
\hline Wasylij Kjandski & $\begin{array}{l}\text { Ballada rosyjska „Botinki w Oswencime" In the upper- } \\
\text { right corner, a name of the composer of music, Wasylij } \\
\text { Kjandowski, and an author of words, W. Palczynskaite. A } \\
\text { typescript with the text of a ballad attached to the score. } \\
\text { The material consists of } 2 \text { copies of 4-page stores in } \\
\text { manuscript. Post-war compostion. [PMO-II-4-197/1,2] }\end{array}$ \\
\hline $\begin{array}{l}\text { music: Gracjan } \\
\text { Guziński „Jasio" / text: } \\
\text { Konstanty Świerk }\end{array}$ & $\begin{array}{l}\text { Już przebrzmiał grom—a song. Musical material of the } \\
\text { march, consisting of } 2 \text { cards. A description on the first } \\
\text { page:"Marsz b. więźniów politycznych Już przebrzmiał } \\
\text { grom” (English: "a march of former political prisoners A } \\
\text { thunder has already passed”), below a drawing of barbed } \\
\text { wire and prisoner triangle with a letter “P” in the middle. } \\
\text { Below, descriptions: "Słowa: Konstanty Świerk /+/ Obóz } \\
\text { Konc. Gusen” (English: “Text: Konstanty Świerk /+/ Conc. } \\
\text { Camp Gusen”). On the second and third page, a music } \\
\text { notation and a text of one stanza of a song. Below on the } \\
\text { second page, descriptions: "Dalsze utwory obozowe w } \\
\text { druku: «Golgota» nastrojowa pieśń więzienna, «Pchła» utwór } \\
\text { humorystyczny, «Mazur obozowy» utwór humorystyczny, } \\
\text { «W bratnim szeregu»» «Zew» Marsz Poznań 25.9.1946 cOp. } \\
\text { K.W.K.." (English:“Further camp pieces in print: «Golgotha», a } \\
\text { stirring prison song, «Flea» humorous song, «Camp Mazur» } \\
\text { humorous song, «Appeal» March Poznań 25.9.1946 cop. } \\
\text { K.W.K... Post-war material. [PMO-Il-4-465] }\end{array}$ \\
\hline NN & Deutsche / Marsch-Perle / Potpourri [PMO-II-4-583/61: ZW] \\
\hline
\end{tabular}

\section{Bibliography}

About the Writers. Dr Guido Jochen Fackler, [in:] Music and the Holocaust, website of World ORT Holocaust Music, [online] http://holocaustmusic.ort.org/about-us/about-the-writerso/ [accessed: 11.06.2016]. Archiwum PMA-B, Zespół Oświadczenia, vol. 73, pp. 86-88, the report of Bolesław Majcherczyk.

Archiwum PMA-B, Zespół Oświadczenia, vol. 76, pp. 204-205, the report of Henryk Król.

Archiwum PMA-B, Zespół Oświadczenia, vol. 84, pp. 112-116, the report of Wiktor Zieliński. 
Archiwum PMA-B, Zespół Oświadczenia, vol. 96, k. 16-21, the report of Franciszek Stryj.

Auschwitz 1940-1945. Węzłowe zagadnienia z dziejów obozu, ed. W. Długoborski, F. Piper, Oświęcim 1995.

Bilica K., Laks, Szymon, [in:] Kompozytorzy polscy 1918-20oo, ed. M. Podhajski, vol. 2, Biogramy, Gdańsk-Warszawa 2005.

Bilica K., Muzyka w obozie według Szymona Laksa i innych [in:] "Muzykalia" 2008, z. VI (Judaica 1).

Bristiger M., Wstęp [in:] „Muzykalia” 2008, vol. VI, Judaica 1.

Chmielnik W., Terapeutyczne funkcje muzyki w sytuacji granicznej na przykładzie przeżyć obozu koncentracyjnego, "Sztuka Leczenia" 2010, Nos. 3-4.

Cykowiak Z., Kobieca orkiestra w oświęcimskim obozie, "Pro Memoria" 1996, No. 5 .

Czech D., Kalendarz wydarzeń w KL Auschwitz, Oświęcim 1992.

Denscher B., Fritz Löhner [in:] Lexikon verfolgter Musiker und Musikerinnen des NS-Zeit, [online] https://www.lexm.uni-hamburg.de/object/lexm_ lexmperson_00002627 [accessed: 31.03.2017].

Dunicz-Niwińska H., Drogi mojego życia. Wspomnienia skrzypaczki $z$ Birkenau, Oświęcim 2013.

Fackler G., „Des Lagers Stimme”. Musik im KZ. Alltag und Häftlingskultur in den Konzentrationslagern 1933 bis 1936, Bremen 2000.

Fackler G., Muzyka w obozach koncentracyjnych 1933-1945, transl. into Polish by S. Wieczorek, [in:] "Muzykalia" 2008, vol. VI (Judaica 1).

Frankl V., Człowiek w poszukiwaniu sensu, Warszawa 2015.

Godorowski K., Psychologia i psychopatologia hitlerowskich obozów koncentracyjnych, Warszawa 1985.

Goldensohn L., Rozmowy norymberskie. Oskarżeni i świadkowie w rozmowie z psychiatra, transl. into Polish by A. Weseli-Ginter, Warszawa 2004.

Górniak J., Jeszcze o muzyce w Oświęcimiu, "Ruch Muzyczny" 1946, No. 2.

Grünberg-Rinkleff I., Grothe, Franz (Johannes August), [in:] Grove Music Online, [online] http://www.oxfordmusiconline.com/subscriber/article/grove/music/11836 [accessed: 29.06.2014].

Helman Z., Laks Szymon, [in:] Encyklopedia Muzyczna PWM. Część biograficzna, vol. 5 (KL€), ed. E. Dziębowska, Kraków 1997. 
Jarowiecki J., Przejawy życia kulturalnego w obozach koncentracyjnych, Kraków 1982.

Kaczorowska K., Adam Kopyciński, dyrygent o złotym sercu, "Gazeta Wrocławska" 12.02.2010, [online] http://www.gazetawroclawska.pl/ artykul/220358,adam-kopycinski-dyrygent-o-zlotym-sercu,id,t.html [accessed: 4.01.2016].

Kalcher A., Leo Rostal [in:] Lexikon verfolgter Musiker und Musikerinnen der NS-Zeit, [online] http://www.lexm.uni-hamburg.de/object/lexm_ lexmperson_o0o02268 [accessed: 30.05.2016].

Knapp A., Holocaust [in:] S. Sadie (ed.), The New Grove Dictionary of Music and Musicians, Vol. 13, 2 ed., New York, 2001, pp. 96-112.

Kopyciński A., Orkiestra w oświęcimskim obozie koncentracyjnym, "Przegląd Lekarski" 1964, No. 1.

Kopyciński A., Ruch Muzyczny za drutami Oświęcimia, "Ruch Muzyczny" 1945, No. 5.

Kopyciński A., Skład orkiestry obozowej w Oświęcimiu, "Przegląd Lekarski” 1966, No. 1.

Kulisiewicz A., Z zagadnień psychopatologii muzyki i pieśni w obozach hitlerowskich, "Przegląd Lekarski" 1974, No. 1.

Kupiec J., Cóż po nas zostanie...? Życie i twórczość więźnia obozu Auschwitz Mieczysława Kościelniaka, Oświęcim 2003.

Lachendro J., Orkiestry w KL Auschwitz, "Zeszyty Oświęcimskie” 27 (2012).

Laks A., O moim ojcu Szymonie Laksie i jego książce, "Muzykalia" 2008, vol. VI (Judaica 1).

Laks Sz., Gry oświęcimskie, Londyn 1979.

Laks Sz., Coudy R., Duhamel G., Musiques d'un autre monde, Paris 1948. Lamb A., Berté, Heinrich [Harry], [in:] Grove Music Online, [online] http://www.oxfordmusiconline.com/subscriber/article/grove/music/02899 [accessed: 29.06.2016].

Lamb A., Lincke, (Carl Emil) Paul, [in:] Grove Music Online, [online] http://www.oxfordmusiconline.com/subscriber/article/grove/music/16669 [accessed: 29.06.2016].

Levi E., Graener, Paul, [in:] Grove Music Online, [online] http://www. oxfordmusiconline.com/subscriber/article/grove/music/11578 [accessed: 29.06.2016]. 
Mrowiec M., Sztuka w piekle. Ocalały Chopin, "Dziennik Polski” 27.01.2012.

Naliwajek-Mazurek K., The Functions of Music within the Nazi System of Genocide in Occupied Poland, [in:] W. Klimczyk, A. Świerzowska, Music and Genocide, series «Studies in Social Sciences, Philosophy and History of Ideas», vol. 9, Frankfurt am Main 2015.

Nattiez J.J., M. Bent, R. Dalmonte, M. Baroni, Musiques. Une Encyclopédie pour le XX $X^{e}$ siècle, vol. 1, Paris 2003.

Auschwitz. Nazistowski obóz śmierci, ed. F. Piper, T. Świebocka, Oświęcim 2004.

Potter P. M., Die deutscheste der Künste. Musikwissenschaft und Gesellschaft von der Weimarer Republik bis zum Ende des Dritten Reichs, Stuttgart 2000.

Quignard P., Nienawiść do muzyki, trans. into Polish by E. Wieleżyńska, "Literatura na Świecie" 2004, Nos. 1-2.

Schäffer B., Szymon Laks, [in:] idem, Almanach polskich kompozytorów wspótczesnych oraz rzut oka na ich twórczość, Kraków 1956.

Setkiewicz P., Krematoria i komory gazowe Auschwitz, Oświęcim 2010.

Setkiewicz P., Z dziejów obozów IG Farben Werk Auschwitz 1941-1945, Oświęcim 2006.

Shirley G., Music in the Holocaust. Confronting Life in the Nazi Ghettos and Camps, New York 2006.

Shuldman K., Jazz Survivor. The Story of Louis Bannet, Horn Player of Auschwitz, London 2005.

Siciński A., Pieśń pomogła przetrwać. W 25. rocznicę oswobodzenia Oświęcimia, "Dziennik Ludowy" 1969, No. 22, [copy in:] Archive of PMA-B, The Team of Statement, vol. 72, k. 182.

Sieradzka A., Sztuka w KL Auschwitz, Oświęcim 2016, [online] http:// lekcja.auschwitz.org/pl_18_sztuka/ [accessed: 20.10.2016].

Stachura A., Motyw więźnia w twórczości artystycznej Mieczysława Kościelniaka, Jerzego Potrzebowskiego i Mariana Kołodzieja więźniów KL Auschwitz, MA thesis, Institute of History of Art of the Jagiellonian University, Kraków 2016.

Szczepański I., Häftlingskapelle, Warszawa 1990. 
Tuchowski A., Nacjonalizm, szowinizm, rasizm a europejska refleksja o muzyce i twórczość kompozytorska okresu międzywojennego, Wrocław 2015.

Würz A., Lincke, Paul, [in:] Deutsche Biographie, [online] https://www. deutsche-biographie.de/ppn118573071.html\#ndbcontent [accessed: 31.03.2017].

Zduniak M., Kopyciński Adam, [in:] Encyklopedia Muzyczna PWM. Część biograficzna, ed. E. Dziębowska, vol. 5 (KLŁ), Kraków 1997.

Reportage from a location of Portret Chopina by Mieczysław Kościelniak in the collections of the Museum of Jagiellonian University, [online] http://www.uj.edu.pl/wiadomosci/archiwum-foto-wideo/-/journal_content/56_INSTANCE_s2jraYnlcxoO/10172/13276214 [accessed: 21.06.2016]. Article: Fania Fénelon on the website of the British association "Music and the Holocaust", [online] http://holocaustmusic.ort.org/places/ camps/death-camps/birkenau/fenelonfania/ [accessed: 28.05.2016]. Article: Anita Lasker-Wallfisch on the website of the British association "Music and the Holocaust", [online] http://holocaustmusic.ort. org/places/camps/death-camps/birkenau/anita-lasker-wallfisch/ [accessed: 28.05.2016].

Article: Josef Rixner on the website of Munzinger Online/Personen Internationales Biographisches Archiv, [online] https://www.munzinger.de/search/go/document.jsp?id=00000006582 [accessed: 31.03. 2017].

Article: Hans Ailbout on the website of Hebu Musikverlag GmbH, [online] https://www.hebu-music.com/de/musiker/hans-ailbout.12094/ [accessed: 31.03.2017]. 